This is the pre-print manuscript published in EXPLORATIONS IN ECONOMIC HISTORY: The Changing relationship between inflation and the economic cycle in Italy: 1861-2012.

The final published version is available online at: http://dx.doi.org/10.1016/i.eeh.2014.06.002

(C) [2015]. This mauscript version is made available under the Creative Commons AttributionNonCommercial-NoDerivs (CC BY-NC-ND) 4.0 International License

(http://creativecommons.org/licenses/by-nc-nd/4.0/) 


\title{
The changing relationship between inflation and the economic cycle in Italy:
} 1861-2012

\author{
Alberto Baffigi , Maria Elena Bontempi ${ }^{* *}$ Emanuele Felice ${ }^{* * *}$ and Roberto Golinelli ${ }^{*}$
}

\section{EXPLORATIONS IN ECONOMIC HISTORY (forthcoming)}

\begin{abstract}
The article investigates the relationship between GDP and prices in Italy in the long-run, from the Country's Unification (1861) up to present day. By using the new national accounts data, over the period 1861-2012, we were able to make Italy the third country to have a historical test of the hybrid Phillips curve (in which both the new Keynesian and the backward-looking Phillips curves are tested), together with the UK and the US. How do economic growth and prices interact in Italy's different stages of economic growth? Unlike the US and the UK, where said interaction was already operating in mid-nineteenth century, in Italy the link between inflation and the economic cycle emerged only after the First World War. We argue that this can be explained owing to Italy's different position in the international economic system and the way foreign conditioning factors (the exchange-rate regime and innovation in transportation) influenced the Italian industrialization. Before the First World War, deflation was imported. This turned out to be compatible with some GDP growth, insofar as the deflationist macroeconomic setting favoured capital inflows and technological upgrading. Whereas, from the First World War until the creation of a common European currency, price variations were mainly a consequence of national policies and domestic conditions: the trade-off with the GDP cycle is now manifest, both in the periods of deflation (the interwar years) and in those of inflation (the second half of the twentieth century). Our findings may also have important implications for present day, since price movements are once again, as in the liberal age, largely imported.
\end{abstract}

Index:

1. Introduction 2

2. The different stages of Italy's long-run development ............................................................ 4

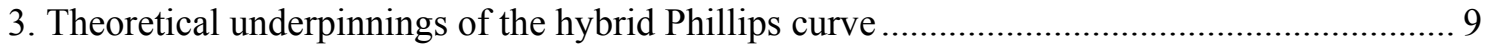

4. Definition and preliminary inspection of the variables of interest..................................... 10

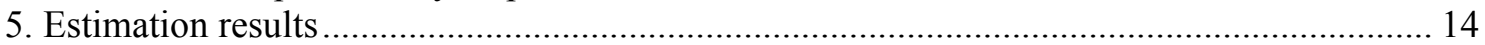

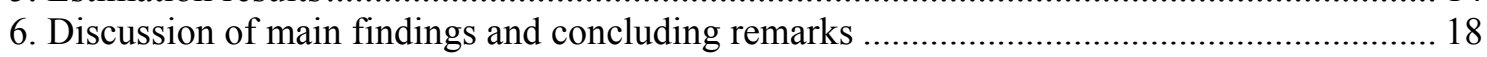

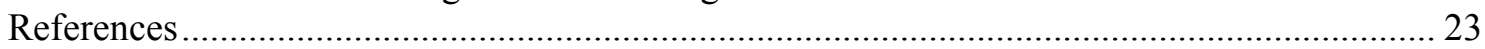

Appendix A1. The methodological heterogeneity of Italy's national accounts historical data... 30 Appendix A2. Extracting potential output and the output gap from GDP ................................. 33

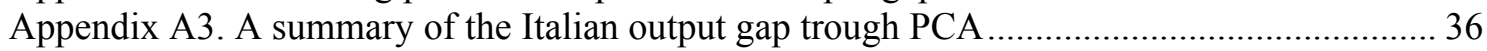

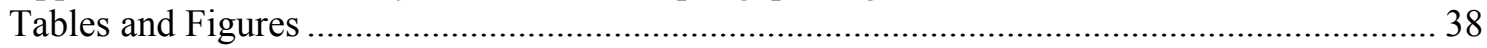

Keywords: long-run perspective; triangle model; New Keynesian Phillips curve; output gap.

Bank of Italy, Servizio Studi di Struttura Economia e Finanziaria. Divisione storia economica e finanziaria (alberto.baffigi@bancaditalia.it)

Department of Economics, University of Bologna, Italy (mariaelena.bontempi@unibo.it and roberto.golinelli@unibo.it)

*** Department of Economics and Economic History, Universitat Autònoma de Barcelona, Spain (claudioemanuele.felice@uab.cat) 


\section{Introduction ${ }^{1}$}

The statistical investigation of the link between inflation and the economic cycle has been at the heart of the macroeconomic debate at least since 1926 with the seminal paper by Fisher. Three decades later, the study carried out by Phillips (1958) laid the basis of the modern approach to this issue: ${ }^{2}$ the so-called Phillips curve is basically related to the existence of a trade-off between stabilizing inflation and stabilizing the gap between the actual and the desired output (see e.g. Gordon, 1990; Mankiw, 2001; Rudd and Whelan, 2007); the latter, called the output gap, can be regarded as an indicator of the economic cycle, insofar as it allows to separate temporary fluctuations (from the demand side) from permanent ones (from the supply side). The relevance of the Phillips curve has been assessed in many different contexts, ranging from inflation forecasting (see e.g. Atkeson and Ohanian, 2001; Stock and Watson, 1999 and 2007) to its implications for the conduct of macroeconomic policy. To this date, however, the empirical long-run studies of the Phillips curve have been few or nothing - if we except the leading cases of the US and the UK - also due to the lack of reliable historical estimates of GDP and prices. $^{3}$ In the past, how strong has the link been between inflation and growth, or between deflation and recession? And how did it change depending on the different monetary regimes, or following the progression in modern economic growth? Little do we know concerning this aspect, and certainly we cannot extend the results of the rather exceptional UK and US economies to the bulk of the less advanced countries.

In this paper, we used the Phillips trade-off as a tool for the analysis of Italy's macroeconomic history, starting from its unification. Hence, we made a first step in bringing the Italian case into a research strand which, until now, has been developed only for the US and the UK. The task was accomplished owing to the availability of the new historical

\footnotetext{
1 An early version of this paper was presented at the workshop "I conti nazionali dell'Italia: la nuova ricostruzione dei dati storici, 1861-2011", Bank of Italy, Rome, April, 16th 2012. We are grateful to, without involving, Fabio Busetti, Stefano Fenoaltea, Andrea Gentili, Vera Negri Zamagni, Gianni Toniolo, Giovanni Vecchi and workshop participants for helpful suggestions. The usual disclaimers apply. Italian MIUR financing is gratefully acknowledged (M.E. Bontempi and R. Golinelli), as well as financial support from the Spanish Ministry for Science and Innovation, project HAR2010-20684-C02-01 (E. Felice).

${ }^{2}$ For a revealing inquiry into the publication story of Phillips' paper - what the website of the host review claims to be "the most heavily cited macroeconomics title of the twentieth century" - see Sleeman (2011, p. 223 for the quotation).

${ }^{3}$ For an overview of the studies about the Phillips curve, see Gordon (2011). The old short survey by Calomiris and Hanes (1994, pp. 10-12) is still a good guide concerning the bulk of studies on the Phillips curve as a tool for macroeconomic history.
} 
national accounts data for Italy collected over the period 1861-2012. Said data are different in many aspects from the previous series, as regards both trends and cycles, especially for the years from 1861 to 1951 , and on the whole significantly more transparent and reliable. ${ }^{4} \mathrm{We}$ followed a path similar to the one marked by Cagan (1975), Sachs (1980), Gordon (1990), Allen (1992) and Hanes (1993) for the US, and by Castle and Hendry (2009) for the UK. We tried to bridge the gap between the study of the changing features of the cyclical pattern of Italy's GDP in a long run perspective - documented by Ciccarelli and Fenoaltea (2007) and Felice and Carreras (2012) - and the corresponding inflation dynamics. The article is an analysis of the link between the real and the monetary aspects of the economy in the long-run: in doing so, we also aimed at establishing new stylized facts concerning the profound structure of the Italian economy, as well as its interaction with international and domestic conditioning factors.

Our main result stands out loud and clear: differently from other countries such as the US and the UK (Phillips, 1958; Sachs, 1980; Castle and Hendry, 2009), in Italy the relationship between inflation and GDP cycles emerged only after the First World War. Before 1914, deflation was imported from the international monetary system (the gold standard) and, indirectly, through technological innovations (railways and steamships). Nonetheless, Italy grew and its modernization did not result in inflationist pressures. On one hand, the Italian economy benefitted from the deflationist fixed-exchange rate regime, which helped to channel foreign capital; on the other hand, the industrial take-off was accompanied by industrial innovation, which resulted in lower inflationary pressures through productivity gains. Whereas from the First World War until the creation of a common European currency, price movements were mainly the result of domestic policies and conditions: the trade-off with the GDP cycle is now clearly visible, both in the periods of deflation (the interwar years)

\footnotetext{
${ }^{4}$ These historical data were collected by the Bank of Italy and Istat in collaboration with the University of Rome "Tor Vergata" (Baffigi, 2011). They are now part of the series included in the first update of the "Maddison project" (Bolt and van Zanden, 2014). Details on sources and methodology of the new series are in the Appendix A1. Previously, Del Boca et al. (2010) had tested the Phillips curve for Italy over the years 1861-1998, but they made use of the old (and by now out-of-date) historical national accounts, from Istat (1957). Besides data, our empirical approach also improves over Del Boca et al. (2010) in several ways, regarding both the specification and the estimation phases of the Phillips curve. Firstly, we extended the model's specification to a number of additional explanatory supply-side shocks (such as energy price and productivity). Secondly, we estimated the parameters with GMM (rather than OLS) because of the model's explanatory variables endogeneity owing to both measurement errors and feedback effects due to simultaneity (e.g. of the output gap), and forward looking price expectations.
} 
and in those of inflation (the second half of the twentieth century). ${ }^{5}$ Our findings concerning Italy's liberal age may have important implications for present day: as of the creation of the Euro, Italy has returned to a situation in which price movements are imported with strong deflationist pressures. However, these may not be necessarily linked to GDP depression, provided that there must be substantial productivity gains.

The paper is organised as follows. Section 2 sketches out the contours of Italy's economic growth from the Unification to present day, aiming at illustrating the cyclical movements and trends in the series of output, productivity and prices. Section 3 introduces the model on the basis of the relevant literature. Our specification builds upon Gordon's triangle model (1981), according to which inflation dynamics is explained by means of three basic ingredients: (a) inflation expectations, which in our specification have both forward and backward looking determinants, following the hybrid New Keynesian Phillips curve (NKPC) created by Galì and Gertler (1999); (b) demand shocks, measured by the output gap; (c) supply shocks coming from abroad (e.g. import prices), from production and technology (i.e. labour productivity), and other random disturbances. Section 4 inspects the main statistical features of the series of interest, i.e. inflation and output gap. The first differences in $\log$ levels of GDP deflator are - as usual - the inflation measure, and the unobservable cyclical situation of the demand is extracted from log-levels of the actual GDP on the basis of nine alternative approaches/filters and their principal component, as detailed in Appendixes A2 and A3. Section 5 reports both GMM and OLS parameters' estimates of the same specification over different subsamples of the whole 1861-2012 period in order to assess the stability over long time spans of the Phillips curve in explaining the Italian inflation rate. In Section 6, the main findings are discussed and put into an international comparison.

\section{The different stages of Italy's long-run development}

Italy's post-Unification economic history can be divided into three main periods: the liberal age (1861-1913), the interwar years (1914-1938), and the republican epoch

\footnotetext{
${ }^{5}$ These results are significantly different from those obtained by Del Boca et al. (2010 and 2012), who instead, making use of the old Istat series of national accounts, found either the conventional negative feedback from cyclical conditions to inflation through most of the 1861-1998 years (with the exceptions of the two world wars and the post-Bretton Woods inflation), or non-significant estimates. However, said results can be due to estimation biases emerging from endogeneity and to the omission of relevant variables. For example, the omission of the productivity shocks in the first part of the sample (up to 1913) could explain the negative sign of the output gap parameter.
} 
(1951-2013). This periodization follows the Country's different political phases and, at the same time, is consistent with the major changes occurred within the international economic system. The yearly growth rates of output, productivity and prices, for the main periods and sub-periods, as well as for the whole sample, have been summarized in Table 1.

\section{Table 1 here}

During the liberal age, output grew at a relatively low rate and productivity lagged somewhat behind. In both cases, a discontinuity is recorded around the middle of the 1890s, when growth accelerated. ${ }^{6}$ The break, however, is much more impressive in terms of prices and appears more pronounced with our data compared to what provided by the official index of consumer prices. In fact, all three deflators - GDP, private consumption and imports decreased from 1861 to 1895 , but increased from 1895 to 1913. It is also worth noticing that, in the first part, it is the deflator for imports of goods and services that, by far, decreased the most. The "great deflation" (roughly 1870-1890) was a world-scale process: even Italy was affected $^{7}$ importing from the outside a reduction in prices.

At that time, there were two powerful forces that brought about a reduction in prices, both external to the Italian context and referable to the so-called first globalization (1870-1913). One was the increase in international (and intercontinental) trade due to the fall of transport costs caused by industrial innovation, from railways to steamships. ${ }^{8}$ The arrival in Europe of cheap agricultural products from land abundant countries coupled with the extension of the industrial way of production to manufactures and agriculture, contracting the prices of both primary and industrial goods. In this respect, the European deflation was part of a more widespread convergence in prices between Europe and the US (O'Rourke and Williamson, 1994), and Europe and Asia (Findalay and O’Rourke, 2007). ${ }^{9}$ It must be added

\footnotetext{
${ }^{6}$ This also corresponds to a long-run change in the composition of the industrial output towards advanced manufactures and consumption-related industries (Felice and Carreras, 2012). For a recent reappraisal of Italy's economic growth during the last decades of the liberal age, see also Sella and Marchionatti (2012).

${ }^{7}$ E.g. Ciocca, 2007, pp. 112 and passim. Starting from the 1880s, electrification also had a role in this reduction: the Centre-North of the peninsula was rich in hydroelectricity, and the construction of hydroelectric power stations allowed Italy to reduce expensive coal imports (Bardini, 1998).

${ }^{8}$ As well as through the opening of the Suez Channel and by technological improvements in communications (telegraphic and later telephonic lines). According to Estevadeordal et al. (2003), the rise of world trade was favoured, above all, by the reduction of transport costs on maritime routes; whereas, maritime transport costs rose during the interwar years (because of a combination of restrictive cartels and labor practices, as well as technological change), and this contributed to the contraction of world trade in that period.
}

${ }^{9}$ Although, indeed, it may have begun some decades before the globalization era (Federico and Persson, 2007). 
that, starting in the $1870 \mathrm{~s}$, governments reacted to falling transport costs by raising tariffs. ${ }^{10}$ In Italy the first tariffs were introduced in 1878, to be later reinforced in 1887; but on the whole, Italian protectionism may be considered mild and ineffective (Federico and Tena, 1998). ${ }^{11}$

The second reason behind the reduction in prices was the international monetary system in force at that time, that is the gold standard which connected most of the countries worldwide by fixed exchange rates (in turn, based upon the free conversion of the national currency to gold, on a fixed parity): through a "common currency" effect, the gold standard significantly favoured not only the increase of capital movements, but also the trade boom (Estevadeordal et al., 2003). Moreover, the gold standard was inherently deflationist and under the active supervision of the Bank of England which effectively led discount rates abroad and was pro-deflationist so as to preserve the value of British assets (Eichengreen, 1987); the costs of adjustments to maintain the fixed parity were higher, and the resulting deflationist policies stronger for peripheral and semi-peripheral countries than for the core countries (Eichengreen, 2008, pp. 24-42; Ferguson and Schularick, 2012). For about half of the liberal age, Italy was attached to the gold standard. The new Reign entered the international monetary system as a bimetallic country (gold and silver), formally accepting the gold standard rule, on a French pattern. However, free conversion was soon suspended in 1866, at the outbreak of the third war of unification with Austria, and it was resumed only in 1883. Formal attachment was short-lived, but even after the end of free conversion, Italy de facto maintained the parity with the gold standard from 1883 to 1893, and then again from 1899 until the outbreak of the First World War (James and O'Rourke, 2013, pp. 51-52; Fratianni and Spinelli, 1984). In short, Italy belonged to the gold standard during the very years of its most intense economic growth. The fixed-exchange compromise was, in fact, decisive for the Country's growth, as it benefitted from the inflows of foreign capitals (Fenoaltea, 1988), at first especially British and French, and then in the last phase above all German (Daudin et al., 2010, p. 12). At that time, Italy behaved as, and was, a peripheral country, unable to maintain formal free conversion, struggling to remain close to the gold standard parity since this would have helped to channel foreign credits which in turn would have made the industrial take-off possible. At the same time, in order to remain within the

\footnotetext{
${ }^{10}$ Arguably, though, these had a minimum role before the Great War, unlike afterwards (Estevadeordal et al., 2003).

${ }^{11}$ In line with this interpretation, recent research suggests that during the liberal age the growth of imports was not only significant, but even favoured, unlike with the following ages, GDP growth (Pistoresi and Rinaldi, 2012).
} 
gold standards, Italy - as all the countries experiencing deficits in their current accounts ${ }^{12}-$ had to follow the deflationary rule, as well as the discount rate policy of the Bank of England.

As known, the shape of the international economy changed dramatically with the outbreak of the First World War. The gold standard disintegrated and each country embarked on its own macroeconomic path. The return to a fixed exchange-rate system and the resurgence of international trade in the 1920s were troublesome and ephemeral issues. The 1929 crisis marked the ultimate end of the traditional gold standard and a turn towards more protectionist policies, which in some cases - Italy included - bordered towards autarchy. As for the gold standard, Italy had returned to it in 1927 at a parity which meant a considerable overvaluation of the lira (Cohen, 1972), and this in turn caused deflation; price reduction continued in the first half of the 1930s, following the 1929 crisis. New inflationist pressures, however, began in 1935, coinciding with the Ethiopian war (1935-36), and later on with the rearmament and the Second World War. It is worth noticing that, at the same time, the Italian economy continued to modernize, especially from 1922 to 1938 when the growth rates were even above those of the late liberal age (see Table 1), although productivity continued to lag behind. With the "roaring" 1920s marking an unprecedented expansion in both output per capita and productivity, cyclical differences were much more pronounced; whereas, in the 1930s, output actually declined, and the same can be said for the total factor productivity. Amidst these ups and downs, the forces behind the change in monetary regimes were mainly domestic, internal: unlike the previous period, international trade remarkably shrunk and was no longer able to significantly affect internal prices. The gold standard, instead, either lost its transnational power, or entirely disappeared. ${ }^{13}$ Thus, re-valuation or de-valuation was the ultimate result of independent national decisions. To some degree, it was also the result of the changing industrial structure of Italian capitalism: new estimates for market competition (Giordano and Giugliano, 2014) indicate a significant rise in the manufacture concentration index, and thus, from 1926-27 to the Second World War, ${ }^{14}$ a shift of the competition regime

\footnotetext{
${ }^{12}$ Italy scored a negative balance of payments current account throughout and after the liberal age (Baffigi, 2013).

13 In some cases, as in Japan, even only speculations of a departure from the gold standard helped to escape from the Great Depression, since they created powerful inflationary expectations (Shibamoto and Shizume, 2014).

${ }^{14}$ In contrast with previous estimates which instead suggested no significant break between the 1930s and the early fascism and liberal age (Rossi and Toniolo, 1992, p. 561; Giannetti and Vasta, 2006). For a discussion of the different estimates, see again Giordano and Giugliano (2014, pp. 7-9).
} 
from "semi-competitive" to "nearly monopolistic." Industrial cartels led to inflationist pressures, as a response to the deflation that followed the 1929 crisis.

After the Second World War, the new Italian republic benefitted from an unprecedented growth in productivity and above all in output, which characterized the years of the "economic miracle" (1951-1973). However, the growth rate decelerated from 1973 to 1992 and then, more markedly, during the "second Republic", that is from 1992 onwards; in this last stretch, even the growth of TFP was negative. The movements in prices changed as well: inflation was now the rule, almost uninterruptedly from the end of the Second World War until present day, with a few deflationist exceptions $(1950,1959)$, and an impressive burst in the 1970s and 1980s. Meanwhile, the international setting shifted dramatically towards a new age of integration in capital and product markets, which in the last decades has become known as the second globalization era. Following the Bretton Woods agreement (1944), a new international monetary system - the gold exchange standard - entered into force until 1971, and Italy adhered to it. Nevertheless, it is worth noticing that the Bretton Woods system, establishing checks on short-term capital flows and allowing for some variation in the exchange rate, unlike the classical gold standard made autonomous monetary policies possible (Eichengreen and Kenen, 1994; Durré and Ledent, 2014). When the system collapsed in 1971, fixed exchange rates were never resumed on a worldwide scale: in Italy, currency rate devaluation and inflation were generously practised until the early 1990s, as well as the new constraints resulting from the commitment to the common European currency. On the other hand, during the golden age, the growing trade integration favoured price reduction (mostly through the low prices of imported energy and natural resources), as exemplified by the slow growth of M deflator in Table 1 from 1951 to 1973. Some price containment did take place also from the 1980s to the new millennium, owing to cheap manufactures (and later services) from resurgent Asian countries as well as to an oil countershock in 1985. However, after the end of Bretton Woods, lira devaluation resulted in the increase in prices of imported goods. To sum up, in the post-Second World War period the deflationary pressures coming from abroad were not enough to compensate the effects of domestic inflationist measures and forces (as the expansive role of the credit system in financing industrial growth). ${ }^{15}$ Once again, in these years variations in the general level of prices were, for the most part, the

\footnotetext{
${ }^{15}$ Rota (2013). A thorough recontruction of the evolution of the credit sector in Italy, based on the new national accounts, is now provided by De Bonis and Silvestrini (2014).
} 
results of national policies and conditions; but now, unlike during the interwar periods, they led to inflation, rather than to deflation. In this respect, things changed only with the creation of the Euro, when decisions on monetary policy were transferred to the European central bank.

\section{Theoretical underpinnings of the hybrid Phillips curve}

The theoretical framework of this work is inspired by a general formulation of Gordon's triangle model (1981), revised and reintroduced in Gordon (1988), where inflation, $\pi_{t}$, is explained through three basic determinants: inflation dynamics-expectations $\left(E_{t} \pi_{t+1}\right)$; demand shocks (excess demand, $x_{t}$ ); supply shocks (cost push, $e_{t}$ ). In symbols:

$$
\pi_{t}=\alpha E_{t} \pi_{t+1}+\beta x_{t}+e_{t}
$$

Compared to the original Phillips formulation, three distinguishing features of specification (1) stand out immediately: (a) the dependent variable is not wage growth but inflation rate $\pi_{t}{ }^{16}$; (b) the role of the excess demand variable $x_{t}$ is not played by the rate of unemployment (or by its difference with respect to some long-run reference level), but is measured by the output gap; ${ }^{17}$ (c) inflation dynamics is explicitly modelled through the $E_{t} \pi_{t+1}$ term, while the Phillips formulation was static (in fact, only contemporaneous terms were used, as was quite usual at that time; see Granger and Jeon, 2011).

Our specification has also three other distinctive features.

First of all, equation (1) is a "hybrid" Phillips curve encompassing two competing theoretical models of inflation - the traditional Keynesian model and the New Keynesian Phillips curve (NKPC) - depending on the way expectations and supply shocks are modelled. In line with the traditional Keynesian approach, Gordon assumes backward looking expectations that lead to explanatory inflation inertia in the triangle model (1). On the contrary, in the NKPC forward looking expectations are assumed: actual inflation is not characterized by inertia, and expectations react to expected policy changes. We measured

\footnotetext{
${ }^{16}$ The recent practice of focusing on the inflation rate (usually measured in terms of GDP deflator) is due to broader interests in inflation issues instead of in only a part if it (i.e. labour costs), and is motivated by the idea that inflation and wages do not have strongly different structural interpretations; see Sims (1987).

${ }^{17}$ Under the assumption of the empirical validity of the Okun's law (1960), the measurement of $x_{t}$ with either the unemployment rate or the output gap should not relevantly affect the sign and significance of model (1) estimates. Further discussion on this issue may be found in Section 5.
} 
expectations with both lagged and future inflation (see Fuhrer and Moore, 1995, and as well as Galì and Gertler, 1999, for similar specifications).

Secondly, we defined the supply shocks as $e_{t}=\gamma z_{t}+\varepsilon_{t}$, where the part $\varepsilon_{t}$ captures random and uncorrelated stochastic disturbances, and the part $z_{t}$ explicitly measures some supply shocks, like the change in relative prices of imports (due to energy price shocks, oneoff price control measures, etc.) and productivity shocks. The Keynesian approach, by assuming $\gamma \neq 0$, explicitly lists the supply shock determinants of the model separately from $\varepsilon_{t}$. On the contrary, the NKPC assumes $\gamma=0$ and, therefore, all supply shocks affecting inflation appear in $\varepsilon_{t}$; of course, if the variables excluded by the NKPC model are significant explanations of inflation and, at the same time, are correlated with the output gap, the estimates of the effects of the output gap on inflation will be biased.

Thirdly, we followed an uniequational approach interpreting it as a reduced form in which both endogeneity and measurement error problems are addressed by using the instrumental-variables GMM estimator (Hansen, 1982).

\section{Definition and preliminary inspection of the variables of interest}

\section{The inflation measures}

We used the information content of four inflation measures, calculated as logarithmic first differences of: 1) GDP deflator; 2) private consumption deflator; 3) imports of goods and services deflator; and 4) cost of life index, i.e., the Istat "index of consumer prices for families of blue- and white-collar workers". ${ }^{18}$ The dynamic features of the measures of inflation (i.e. magnitude, persistence, variability and timing of the shocks undergone) are relevant for valid inferences on model (1)'s parameter estimates, as the GMM estimator assumes variables generated by stationary stochastic processes. Table 2 reports, along different rows, the results from the DF-GLS unit root test (Elliot et al., 1996), and other statistical indicators coming from the univariate representation of inflation measures, i.e. a second-order autoregressive model, $\operatorname{AR}(2)$, which is sufficient to fully explain inflation dynamics. The stability of the

\footnotetext{
${ }^{18}$ The first three time series are from Baffigi (2011); for details, see the Appendix A1. The time series of the index of consumer prices for families of blue- and white-collar workers is available starting from 1861, and can be downloaded from Istat's website (Istat, 2013).
} 
results over time is tested throughout the full period (1864-2012) ${ }^{19}$ as well as the three subperiods 1864-1913, 1914-1938 and 1951-2012 (along different columns of Table 2).

\section{Table 2 here}

The tendency of inflation to increase its persistence over time, as already highlighted by the literature for the US in the second half of the twentieth century, ${ }^{20}$ is also confirmed for Italy. In the last column of Table 2, regarding the 1951-2012 period, the sums of the two autoregressive parameters (ar $1+a r 2)$ for GDP and private consumption deflators and, to a lesser extent, for the cost of life index are very close to one, i.e. to the upper limit of nonstationarity. Inflation inertia was not a fundamental determinant of inflation in the first two sub-periods (1864-1913 and 1914-1938), explaining only about $20 \%$ and 30-40\% of domestic inflation variability (see the $\mathrm{R}^{2}$ ), while in the third period (1951-2012) inertia is so high that, alone, it can explain more than $80 \%$ of inflation variability over the sub-period. This evidence of non-stationarity is further corroborated by DF-GLS test statistics which fail to reject the null hypothesis of unit roots in the 1951-2012 sub-sample for all the four measures of inflation. $^{21}$

The variability of shocks to inflation (labelled as $\hat{\sigma}$ in Table 2 ) is time varying as well: it is the highest in the period 1914-1938, while it is quite low in the third part of the sample (1951-2012). For this last period, however, it must be noted that the variability of imported inflation (imports of goods and services) reached a level about four times higher than that of domestic inflation (private consumption). This can explain the presence of autoregressive conditional heteroscedasticity over the full sample, which in the last sub-sample - for GDP and private consumption inflation - is probably due to energy shocks. Robert Engle describes a similar pattern for the UK, limitedly to the years from 1958 to 1977, with the estimated variances increasing "substantially during the chaotic seventies" (Engle, 1982, p. 987).

Regarding inflation behaviour across the four measures, the dynamics of the cost of life index remain in the middle between GDP and imports inflation rates, and usually close to

\footnotetext{
${ }^{19}$ Note that the first three years of the whole period 1861-2012 are lost due to the dynamics of model (1) and to the lags used as instruments for GMM. Moreover, we deliberately excluded the 1939-1950 years because of their big anomalies due to World War II. Finally, we tested the robustness of the results to the exclusion of years 1914-1921, i.e. those affected by World War I (see Section 5 for details).

${ }^{20}$ See in particular Gordon, 1981, Table 3, for the years 1954 to 1980.

${ }^{21}$ Similar results were reached by Del Boca et al. (2010).
} 
private consumption inflation, given that it is an average of the prices of domestic and imported goods and services.

Following much of the empirical literature, and given the results in Table 2, we measured inflation with the first-differences of the log-levels of the GDP deflator. In fact, the aim of the NKPC is that of modelling the behaviour of domestic (and not foreign) inflation, summarised by GDP inflation. However, in order to assess the robustness of our outcomes, we also estimated the model's parameters by using inflation measured on the basis of the cost of life index. If relevant measurement errors (noise) obscure inflation signals, we can expect that alternative inflation measures should lead to quite different outcomes.

Imported inflation dynamics (more volatile and less inertial than the others) corroborate our choice of including import prices shocks in the supply shocks vector $z_{t}$ of equation (1). In addition, we also used energy prices expressed in foreign currency (e.g. coal prices in UK Pounds per ton, and oil price in US Dollars per barrel) as external instruments. The firstdifferences of log-levels of the private consumption deflator, being a mixture of domestic and imported inflation, can be used as an external instrument in the estimation phase of the model.

\section{The measurement of the output gap}

The output gap is the difference between actual and potential output; it is an indicator of the economic cycle, as it allows to disentangle demand fluctuations (the cycle, which causes only temporary output changes) from the fluctuations coming from the supply side (those inducing permanent changes in the output).

We used alternative statistical techniques to extract the potential output from actual GDP log-level data: segmented trends, filters and univariate decompositions, and models with unobservable components. In particular, nine statistical techniques were selected and nine alternative potential output estimates were obtained. The difference between GDP log-levels and these alternative estimates led to nine alternative measures of the output gap $\delta_{t}^{i}$, ${ }^{22}$ where $i$ is equal to: PTPT (peak-to-peak trend); TSOLS (restricted segmented trends with OLS); BP (endogenous break date algorithm of Bai and Perron, 1998 and 2003); BN (decomposition of Beveridge and Nelson, 1981); UCMLT (local linear trend model of Harvey and Jaeger, 1993); HP100 (filter with $\lambda=100$ of Hodrick and Prescott, 1997); HP625 (HP filter with $\lambda=6.25$ of

\footnotetext{
${ }^{22}$ Given that we worked with output levels transformed in logarithms, the output gap measures the percent discrepancy between the amount of actual output and what could be expected if the economy were operating at its sustainable (potential) level. Therefore, when the gap is zero there is neither excess of demand nor excess of supply and the economy can be seen as in equilibrium at its supply-determined potential.
} 
Ravn and Uhlig, 2002); BK (band pass filter of Baxter and King, 1999); CF (band pass filter of Christiano and Fitzgerald, 2003). Technical details are in Appendix A2.

These nine $\delta_{t}^{i}$ measures were first normalized (mean zero and unit variance) and then reported in three different plots (by subsample of interest) of Figure 1; in order to improve readability, recession phases (as identified in Baffigi et al., 2013, Table 4) are represented with shaded areas. The visual inspection of the time pattern of the gaps shows a lot of communality which suggests to summarize the gaps with the first principal component calculated through Principal Components Analysis (PCA), as detailed in Appendix A3.

\section{Figure 1 here}

PCA-extraction results show that the first principal component of the nine output gap measures can explain about $70 \%$ of total variability: the correlation between our nine output gap measures is so high that their core information may be synthesized by just one time series, $f_{t}$, which can substitute explanatory variable $x_{t}$ in model (1).

In order to verify the robustness of our $f_{t}$ estimates, Figure 2 shows the graph of two alternative principal components estimates: ${ }_{1} \hat{f}_{t}^{1}$ is obtained from separated loadings for each sub-period; ${ }_{1} \hat{f}_{t}^{2}$ is obtained from a unique loadings for the whole period (see Appendix A3). The first three quadrants show the time profile of ${ }_{1} \hat{f}_{t}^{1}$, while the last quadrant - bottom right plots both ${ }_{1} \hat{f}_{t}^{1}$ and $\hat{f}_{t}^{2}$.

\section{Figure 2 here}

The peak and trough dates identified by Baffigi et al. (2013, Table 4), on the basis of all the nine different gap measures, are confirmed by the factorial synthesis in ${ }_{1} \hat{f}_{t}^{1}{ }^{23}$ In addition, it is worth noting that the nine output gap measures are noisier than the synthesis provided by the principal component (compare the patterns in Figure 1 and 2).

The two components ${ }_{1} \hat{f}_{t}^{1}$ and ${ }_{1} \hat{f}_{t}^{2}$ plotted in the bottom right part of Figure 2 show a coincident cyclical profile, especially with reference to the points where the zero line is crossed. However, the relative amplitude of cyclical fluctuations (variability) differs between

\footnotetext{
${ }^{23}$ A similar business cycle dating is obtained by Clementi et al. (2014).
} 
the two time series. The extraction of factors by sub-periods $\left({ }_{1} \hat{f}_{t}^{1}\right)$ or over the whole sample $\left({ }_{1} \hat{f}_{t}^{2}\right)$ involves output gap measures normalised with respect to different standard deviations. Clearly, the conditional variance of ${ }_{1} \hat{f}_{t}^{1}$, which has been normalised with different variability estimates by sub-period, does not exhibit the autoregressive conditional heteroscedasticity which instead affects $\hat{f}_{t}^{2}$.

\section{Estimation results}

In symbols, the empirical specification of the hybrid Phillips curve in equation (1) is:

$$
\pi_{t}=\alpha_{0}+\alpha_{f} \pi_{t+1}+\alpha_{b} \pi_{t-1}+\beta_{1} \hat{f}_{t}^{2}+\gamma_{m} z_{t-1}^{m}+\gamma_{\eta} z_{t-1}^{\eta}+\varepsilon_{t}
$$

where $\pi_{t}$ is the first difference of the GDP deflator logarithm; $\hat{f}_{t}^{2}$ is the output gap measured as the first principal component obtained through a single estimate over the whole sample period; ${ }^{24}$ the supply shocks that we explicitly modelled are two: the first difference in logs of the deflator of imports of goods and services $\left(z_{t-1}^{m}\right)$, and the growth rate of the total factor productivity, TFP $\left(z_{t-1}^{\eta}\right)^{25} ; \varepsilon_{t}$ represents all other iid supply shocks not explicitly modelled. The theoretical predictions of the signs of model (2) parameters are: positive for

\footnotetext{
${ }^{24}$ The use, in model (2), of the principal component obtained from specific loadings by sub-periods $\left({ }_{1} \hat{f}_{t}^{1}\right)$ leaves the estimation results virtually unchanged.

${ }^{25}$ We estimated three alternative TFP measures, all from a growth accounting exercise (Solow's residuals). The data to feed the constant return to scale Cobb-Douglas production function (i.e. employment and capital stocks) are from Broadberry et al. (2011). Our different TFP measures correspond to different ways to measure the output elasticity to labour: two of them use the wage share in GDP (wage data were kindly provided by Claire Giordano and Francesco Zollino; see Giordano and Zollino, 2014), the third uses the residuals of an estimated Cobb-Douglas production function. In the first two cases, the wage share time series is smoothed with: $(i)$ Hodrick and Prescott (1997) filter with $\lambda=100$ (HP100) in order to obtain very slow shares' fluctuations over time; (ii) segmented averages over homogeneous subperiods: 1861-1874, 1875-1913, 1914-1938, 1950-1969, 1970-1989, and 1990-2012. The three alternative estimates are very close to each other and to those plotted in Broadberry et al. (2011, p. 42). In Table 3, we report results from TFP estimates with HP100 filtered wage shares; the other measures deliver very similar outcomes.
}

Although TFP shocks should capture technological shocks more efficiently than labour productivity (i.e. GDP per worker), the two measures are strongly related. The use of labour productivity growth rather than TFP growth in equation (2), as in Baffigi et al. (2013, Table 7), does not qualitatively alter the main findings reported below. In the following pages, we will deepen the comparison.

The timing of the variables $z$ measuring the supply shocks (i.e. in $t$ or in $t-1$ ) is broadly irrelevant, as it does not lead to qualitatively different estimation results. 
$\alpha_{f}, \alpha_{b}, \beta, \gamma_{m}$, and negative for $\gamma_{\eta}$. When significant, we also reported the effect on inflation rates of changes in $t$ of the nominal exchange rate of the Italian lira (otherwise hidden in $\varepsilon_{t}$ ); being in $t$, lags of the exchange rates are the corresponding (internal) instruments.

Estimation results of model (2) are reported in Table 3: parameters are in bold characters and below there are the corresponding standard errors. The GMM instruments are: the lags from $t-1$ to $t-3$ of inflation (measured by both GDP and private consumption deflators); the lags from $t$ (because they are assumed to be exogenous) to $t-2$ of energy prices in foreign currency (coal prices in UK Pounds per ton, and oil price in US Dollars per barrel); ${ }^{26}$ the lag $t-1$ of the labour productivity and of the imports deflator growth; and the lags $t-1$ and $t-2$ of the output gap and of TFP growth. Regarding exogenous energy prices, it is worth noting that their use as instruments parsimoniously offsets the omitted variables bias, that otherwise would arise from their exclusion in the list of equation (2) regressors.

\section{Table 3 here}

The results refer to the same three sub-periods defined above, ${ }^{27}$ and are delimited with vertical lines in three blocks of columns. The columns inside each block report the estimation results of alternative specifications of the mechanism of expectations formation, as well as of the robustness of our results when the inflation rate is measured by the cost of life index rather than by GDP deflator (details are below).

$1864-1913$

Regarding the results for the 1864-1913 sub-period, column (1) reports GMM estimates of the hybrid NKPC (see, for example, Galì and Gertler, 1999), as the specification includes a

\footnotetext{
${ }^{26}$ Data from 1861 to 1939 are from Istat, Annuario Statistico (various years), where import prices per ton of both coal and oil in Italian liras are reported (they were respectively converted into UK pounds and US dollars). From 1949, the oil price in US dollars per barrel is the average of the four oil prices reported in the World Bank's Pink Sheet, reporting the time series of various commodity price data. The resulting complete oil series is very close to that in BP Statistical Review of World Energy of 2013. Coal prices up to 1911 are very close to those reported in Bardini (1998); after 1939 they were no longer used as external instrumental variables because not as representative as before.

${ }^{27}$ When applied to the whole sample period (1864-2012), the algorithm of Bai and Perron (2003) suggests a single break (in 1915) for the parameters of model (2); with little surprise, this was the year of Italy's entry in the Great War. However, given the proximity of such a break point with the 1913-1914 years (i.e. when the first subsample ends and the second starts), we chose to maintain the three sub-periods as defined throughout the paper, rather than adding further sample splits.
} 
lead and a lag of inflation. ${ }^{28}$ Parameter $\beta$ point estimate measures an output gap effect on inflation which has a wrong (negative) and not statistically significant sign. ${ }^{29}$ On the other hand, the TFP shocks are both economically and statistically significant: a $1 \%$ increase of the TFP growth leads to a similar reduction in the domestic inflation rate. The same is true, albeit slightly less significant, for the imported inflation shocks.

Owing to the non-rejection of the restriction $\alpha_{f}+\alpha_{b}=1$ (the parameters measuring inertia and expectations tend to add up to one), in column (2) the constraint is imposed to model parameters. The restricted GMM estimates are in line with those in column (1), and this outcome is very relevant, because - as shown in Henry and Pagan (2004) - when forward and backward expectations parameters are restricted, GMM estimates are less affected by the identification problem discussed in Rudd and Whelan (2005). In fact, with the above restriction imposed to data, internal instruments are shown to perform better. This result, supporting our GMM approach, is also confirmed in the 1914-1938 sub-period; corresponding results are in columns (4) and (5).

In column (3), domestic inflation is measured by the cost of life index inflation instead of by the GDP deflator inflation. Even though this measurement change can be seen as a robustness check of the previous outcomes, we must acknowledge that the cost of life is (by definition) an average of domestic and imported goods. Given that the price setting of the imported goods is made abroad, it is reasonable that both the inflation dynamics and the effects of the other inflation determinants are different. This caveat applies also when discussing the results in columns (7) and (11) regarding the other two sub-periods.

However, it is remarkable that, despite this mixture of economic signals and (potentially) different measurement errors embodied by the two alternative indicators, the

\footnotetext{
${ }^{28}$ Apart from the addition of two explanatory variables (imports inflation and TFP growth) as proxies for supply shocks. A third additional regressor (the exchange rate of Italian lira against the UK pound) is not listed because largely not significant, as expected in the light of the exchange rate regimes (as mentioned in Section 2, Italy was attached to the gold standard for about half of the liberal age, with a resulting fixed exchange rate with the UK pound).

${ }^{29}$ Sometimes the negative sign for the output gap can be attributed to its dynamics not being consistent with the corresponding rate of unemployment; in particular historical phases, it could be that negative (positive) gaps are not associated to rates of unemployment above (below) the long run reference level; see Rudd and Whelan (2007). Since unemployment rate observations are not available for this subsample, the comparison of the output gap and of the unemployment rate dynamics cannot be replicated for Italy. It can also be noticed that, in some historical phases, the output gap anticipates inflation with a positive sign (as it can be expected as a result of a demand shock), while in other periods (when the economy is mainly affected by supply shocks) inflation tends to lead the output gap with a negative sign. Given the presence of highly variable and short cyclical phases in the first 50 years of Italian history, it cannot be excluded that the two effects tend to blur, also because of the low frequency (annual periodicity) of data.
} 
estimation of the cycle on inflation in the first three columns of Table 3 is the same, not being significant.

$1914-1938$

The estimates for the middle period 1914-1938 in columns (4)-(7) reflect the existence of a clear trade-off between inflation and economic cycle, independently regarding: alternative NKPC dynamics (unrestricted in column (4) and restricted in column (5)); foreign shock measures, i.e. with or without exchange rate shocks (in columns (6)-(7) and (4)-(5) respectively); and the inflation measure (column (7) reports the unrestricted NKPC explaining the cost of life inflation).

The 1864-1913 reactivity of domestic- to imports-inflation is strongly attenuated over the period 1914-1938, probably because of accentuated restrictions on international trade. However, if we include in NKPC specification the exchange rate shocks - see columns (6) and (7) - the inflation fitting of the NKPC strongly improves (the standard error of the regression drops from above $8 \%$ to less than $6 \%$ ). The marginal explanatory effect of the sizeable fluctuations in the exchange rate against the UK Pound also contributes to estimate all the other parameters more precisely, which however remain in line with the results without the exchange rate inclusion. Again, the shift from the GDP deflator in columns (4)-(6) to the cost of life measure in column (7) does not affect the significance of the output gap effect.

Given that this sub-period includes the years of the First World War (WWI), we tested the robustness of the outcomes as regards the shortening of this sample for the period from 1914-1938 to 1922-1938. Although the short span of data suggests careful interpretations, the results (available upon request) confirm all the previously discussed findings, in spite of the shortened period.

1951-2012

Finally, columns (8)-(11) of Table 3 report the post-1950 sample results, in which the most remarkable news (against the past outcomes) is the change in the inflation dynamics: a huge increase in (past) inflation inertia and the reduction in the role played by forward looking expectations. Regarding the latter, the interval estimate of the $\alpha_{f}$ parameter in column (8) is so wide that we do not reject either $\alpha_{f}+\alpha_{b}=1$ or $\alpha_{f}=0$ restrictions. In the first case, the restricted estimates are in column (9) and - since 1864 - for the first time the 
inflation inertia effect is stronger than what expected. In the second case, we have the classical Gordon's triangle model estimates in column (10), where the inertia parameter of the triangle model is also restricted to be one: the stochastic process underlying domestic inflation is persistent as ever before, even not stationary. Despite non stationarity inflation emerging from Table 2, GMM estimates in column (8) are supported by imposing the unit root to inflation (as here the model explains the changes in the domestic inflation rate), and by leaving the effects of other supply-side shocks (namely, import prices inflation and TFP growth) not significant. It is important to notice that such different inflation dynamics do not interfere with the stability and clear significance of the output gap effect. In column (11) the use of the cost of life inflation rescues the supply shocks relevance, without changing the significant role played by the economic cycle.

Overall, the effect of the output gap after 1914 is always positive and at least $10 \%$ significant, regardless of alternative assumptions concerning inflation dynamics, measurement, and supply shocks. Estimates fluctuate in the 0.01-0.02 range. ${ }^{30}$

Given that the output gap is measured as a principal component, it is a zero-mean and a unit-standard deviation variable. If we agree with Fenoaltea and Ciccarelli (2007) to define as "strong" a cyclical peak or trough during which the output gap is greater than one time its standard error in absolute value, all the results in Table 3 suggest that, in the occurrence of a strong peak/trough, inflation is subject to an acceleration/deceleration in the 1-2 percentage points range.

\section{Discussion of main findings and concluding remarks}

The exploration of the trade-off between inflation and the economic cycle in Italy since its unification (i.e. over a span of 150 years) shows that the macroeconomic history can be disentangled in two broad periods (before and after 1913). However, the inflation-cycle tradeoff is detected only in the second period.

In the first period (1861-1913), the results emerging from the econometric analysis point to a not statistically significant estimate of the output gap parameter. The trade-off between cycle (measuring demand shocks) and inflation does not show up in these years,

\footnotetext{
${ }^{30}$ This result is not due to the GMM approach followed in this paper, as Baffigi et al. (2013, Table 7) also report similar outcomes for the Gordon's triangle model estimated with OLS.
} 
while inflation significantly responds to a mix of forward/backward expectations and to productivity (supply) shocks. ${ }^{31}$

This result can be interpreted in the light of the overall macroeconomic conditions of the liberal age. As highlighted, before the First World War deflation was imported: on the one hand, technological innovations in long-distance transports (railways and steamships, above all) favoured the arrival of cheaper products from overseas territories, not adequately offset by the protectionist tariffs raised in Italy; on the other hand, the gold standard posed a strong deflationist constraint on domestic monetary policy, to which Italy had to adapt as most of the semi-peripheral and peripheral areas of that period. ${ }^{32}$ At the same time, Italy experienced its industrial take-off; that is, economic growth with supply-side effects on price reductions, via technological improvements. During the five decades after the unification, productivity shocks - whose relevance emerges in columns (2)-(4) of Table 3 - are clearly behind price fluctuations, together with forward looking expectations. On this background, in the fifty post-unification years, very sharp relative price changes occurred, whose size and speed probably have no equal over the following hundred years. In 1861, the relative deflator at 1911 prices of industry's value added with respect to agriculture was equal to 142 , and the relative deflator of industry with respect to services was equal to 192 (of course, in 1911 all the deflators are equal to 100 by construction). ${ }^{33}$ The structure of the economy underwent deep changes: industry grew and became more productive, with significant effects on its relative prices. It should not be overlooked, however, that this take-off was made possible by the same international setting which favoured deflation: the gold standard facilitated foreign investment, "which lifted the Italian boat as it did others". In fact, as effectively summarized by Fenoaltea (2011, p. 110): "The increase in the supply of foreign capital loosened financial constraints, stimulated investment, raised the equilibrium real exchange rate; it generated a

\footnotetext{
${ }^{31}$ The relevance of the latter effects in explaining inflation fluctuations could explain the significantly negative parameter of the output gap in Del Boca et al (2010) who omit supply shocks from their model.

${ }^{32}$ The fact that, in Italy, the gold standard was associated with lower inflation rates is also confirmed by Del Boca et al. (2010).

${ }^{33}$ The calculations are based on data available on the Bank of Italy's website (see link in the references). Figures 4 and 12 (pp. 46 and 50, respectively) of Baffigi (2011) highlight that the share of industrial value added over the total economy, at current prices, does not show large variations. Similar outcomes were obtained by Fenoaltea (2011) on the basis of different methods. However, this constancy comes from a decrease in prices accompanied by an increase in quantities. It should also be noted that the correlation coefficients between the deflators of the value added of the three macro-sectors show strong specificity in the first five post-unification decades: a positive value (0.66) between agriculture and industry, a negative value (-0.53) between industry and services and, consistently, a value close to zero between agriculture and services. All this should be compared, in the other periods, to values ranging between 0.83 and 0.97 across all sectors.
} 
current-account deficit and a net inflow of resources, and tended to raise wages and consumption." To this, it must be added that machinery imports during the Giolittian era $(1900-1914)^{34}$ were crucial for the Italian industrialization, and comparatively higher than in the 1920s-1930s and even, "mutatis mutandis", in the post-Second World War era (Barbiellini Amidei et al., 2013, p. 394). ${ }^{35}$

Our findings for the Italian case are of particular interest, since they significantly differ from what (not much) known concerning other countries in that period. For the United States, the parameter estimates of the Phillips curve by Jeffrey Sachs (1980), for the years 1890 to 1929, yield the expected results. A trade-off between inflation and unemployment has also been confirmed in the case of the United Kingdom, with data going back to 1860 (Castle and Hendry, 2009). In order to explain this difference with our results, first of all it should be reminded that we did not use unemployment figures, because they are not available for Italy in the long-run, and that of course there could be a discrepancy between output and employment. However, even after allowing for this possible discrepancy, the question remains open. Why is the Phillips curve confirmed for the US and the UK during the gold standard, and it is not (as far as we know) for Italy? A reason could be that both the US and the UK, on different grounds, did not import inflation to Italy's same extent: in the case of the UK, because that was the leading economy, which indeed made the monetary policy for all the international system, mostly through the decisions of the Bank of England on the interest rate; in the case of the US, because owing to the size of their economy they were less affected by foreign conditions, and, above all, because in themselves they were a major world source of the reduction in prices, via exports of cheap industrial and agricultural goods. Admittedly, these are tentative answers. Surely, this argument of ours could benefit from more empirical tests, not only as regards the UK and the US, but also with reference to other European and extra-European countries, a part from Italy.

As far as the post-1913 period is concerned - the second broad section of Italy's "tradeoff" history - we obtained Phillips curve estimates for two distinct sub-periods: 1914-1938 and 1951-2007. The results from the two sub-samples are quite similar, pointing to fairly stable inflation-output gap trade-off, emerging since the First World War. Regarding its

\footnotetext{
${ }^{34}$ After the appointing of the liberal Prime Minister Giovanni Giolitti.

35 The latin expression stays for "the 1950s opening of the domestic market with European integration and international commercial liberalizations, and the new scale of intraindustry trade characterizing the second half of the twentieth century" (Barbiellini Amidei et al., 2013, p. 394).
} 
magnitude, parameters estimates suggest a quite substantial reactivity of inflation to peak and through points of the cycle. With respect to previous findings in literature, the statistical significance of the output gap in explaining Italian inflation dynamics since 1914 can be read as a confirmation and extension of the results in Golinelli (1998), who finds a significant unemployment rate in a backward-looking Phillips curve estimated with cointegration techniques over a sample of forty years, starting in the fifties of the past century (and thus partly overlapping our third sub-period). More or less over the same sub-period, Del Boca et al. (2012), who use a model's specification which is closer to our approach than Golinelli's (1998), find an inflation's dynamics that is very close to ours (i.e. the prominent role played by inflation inertia after WWII), while mixed evidence is reported regarding the cycle-effect on the inflation rate, depending on the filter used to estimate the output gap from GDP. In fact, it is almost $10 \%$ significant when using the Hodrick-Prescott filter, while its significance vanishes when using the structural time series approach. ${ }^{36}$

It has been argued (Correa-López et al., 2013) that the responsiveness of inflation to macroeconomic imbalances is stronger when competition is high, but we have little data to test this nexus in the Italian case. Available measures of competition in Italy declined during the First World War, and then from 1927 to the Second World War (Giordano and Giugliano, 2014, p. 8); probably, also from the mid-1890s to the mid-1900s (Rossi and Toniolo, p. 561). This is likely to have weakened the Phillips curve in those years, while reinforcing the impact of productivity on inflation. After the Second World War, product market regulation decreased, but still remained high throughout the second half of the twentieth century (Rossi and Toniolo, 1996, pp. 430-437). In comparative terms, we also know that, in the last decades of the twentieth century, and still in our days (1998-2003), Italy has scored a significantly high degree of product market regulation, compared to the other OECD countries (Conway and Nicoletti, 2006), and this also is likely to weaken the Phillips curve. Thus far, our findings give little support to this line of interpretation. However, with annual data, the Euro-history available is still too short to allow for a formal assessment of the occurrence of parameters' break (or simply weakening output gap effects) after the introduction of the Euro.

\footnotetext{
${ }^{36}$ Regarding their weak evidence (10\%) of the HP gap significance, it should be noted that the inclusion in our model of significant supply-side oil price and productivity shocks could have improved model fitting and, consequently, delivered more precisely the estimates of the output gap parameter. In addition, it is also important to note that the Hodrick-Prescott and the structural time series filters in Del Boca et al. (2012) are only two out of the nine filters we summarised with our principal components based gap measure, that - further - depicts a cyclical pattern very close to those usually reported in the Italian literature.
} 
Our historical analysis and our results point to a major role played by international monetary regimes, together with industrialization and technological innovation. Important policy implications arise even for present day. In fact, since the introduction of the Euro, as during the Gold Standard era, Italy has entered into a macro-economic setting in which the monetary policy - decided by the European Central Bank - is largely exogenous to the national context. On this background, it is possible to learn about macroeconomic policy through macroeconomic history, and new research perspectives are now open aimed at providing more evidence concerning determinants and causes of the shifts in the parameters of Italy's Phillips curve in the long-run. 


\section{References}

Allen, S.G., 1992. Changes in the Cyclical Sensitivity of Wages in the United States. American Economic Review 82(1), 122-140.

Atkeson, A., Ohanian, L.E., 2001. Are Phillips curves useful for forecasting inflation? Federal Reserve Bank of Minneapolis Quarterly Review 25(1), 2-11

Baffigi, A., 2011. Italian National Accounts, 1861-2011. Bank of Italy, Economic History Working Papers, Number 18 (October). Bank of Italy, Rome. Downloadable at http://www.bancaditalia.it/pubblicazioni/pubsto/quastoeco/QSE_18 (last access on November 2013).

Baffigi, A., 2013. National Accounts, 1861-2011. In: Toniolo, G. (Ed.), The Oxford Handbook of the Italian Economy Since Unification. Oxford University Press, Oxford, pp. 157-186.

Baffigi, A., 2014. Il PIL per la storia d'Italia. Istruzioni per l'uso. Marsilio, Venezia. Forthcoming.

Baffigi, A., Bontempi, M.E., Golinelli, R., 2013. Potential Output, Output Gap, and Inflation in Italy in the Long Term (1861-2010): an Econometric Analysis. Bank of Italy, Economic History Working Papers, Number 29 (February). Bank of Italy, Rome. Downloadable at http://www.bancaditalia.it/pubblicazioni/pubsto/quastoeco/quadsto_29/QSE_29.pdf. (last access on November 2013)

Bai, J., Perron, P., 1998. Estimating and testing linear models with multiple structural changes. Econometrica 66, 47-78.

Bai, J., Perron, P., 2003. Computation and analysis of multiple structural change models. Journal of Applied Econometrics 18, 1-22.

Barbiellini Amidei, F., Cantwell, J., Spadavecchia, A. (2012). Innovation and Foreign Technology. In: Toniolo, G. (Ed.), The Oxford Handbook of the Italian Economy Since Unification. Oxford University Press, Oxford, pp. 378-416.

Bardini, C., 1998. Senza carbone nell'età del vapore: gli inizi dell'industrializzazione in Italia. Mondadori, Milano.

Battilani, P., Felice, E., Zamagni, V., 2012. Il valore aggiunto dei servizi a prezzi correnti (1861-1951). Mimeo, Bank of Italy.

Baxter, M., King, R., 1999. Measuring business cycles: approximate band-pass filters for economic time series. Review of Economics and Statistics 81, 575-593.

Beveridge, S., Nelson, C.R., 1981. A new approach to decomposition of economic time series into permanent and transitory components with particular attention to measurement of the business cycle. Journal of Monetary Economics 7, 151-174.

Bolt, J., van Zanden, J.L., 2014. The Maddison Project: collaborative research on historical national accounts. The Economic History Review 67, DOI: 10.1111/1468-0289.12032.

Broadberry, S., 2005. Appendix: Italy's GDP in World War I. In: Broadberry, S.N., Harrison, M. (Eds.), The Economics of World War I. Cambridge University Press, Cambridge, pp. 305-307. 
Broadberry, S.N., Giordano, C., Zollino, F., 2011. A Sectoral Analysis of Italy's Development, 1861-2011 . Bank of Italy, Economic History Working Papers, Number 20 (October). Bank of Italy, Rome.

Downloadable at http://www.bancaditalia.it/pubblicazioni/pubsto/quastoeco/qse-20/qse-20.pdf. (last access on November 2013)

Broadberry, S.N., Claire, G., Zollino, F., 2013. Productivity. In: Toniolo, G. (Ed.), The Oxford Handbook of the Italian Economy Since Unification. Oxford University Press, Oxford, pp. 187-226.

Brunetti, A., Felice, E., Vecchi, G., 2011. Reddito. In: Vecchi, Giovanni (Ed.), In ricchezza e in povertà. Il benessere degli italiani dall'Unità a oggi. Il Mulino, Bologna, pp. 209-234.

Burns, A., Mitchell, W., 1946. Measuring Business Cycles. NBER, New York.

Cagan, P., 1975. Changes in the Recession Behavior of Wholesale Prices in the 1920's and Post-World War II. NBER, Explorations in Economic Research 2(1), 54-104.

Calomiris, C.W., Hanes, C., 1994. Historical macroeconomics and American macroeconomic history. NBER Working Paper, No. 4935.

Carreras, A., Felice, E., 2010. L'industria italiana dal 1911 al 1938: ricostruzione della serie del valore aggiunto e interpretazioni. Rivista di Storia Economica 26(3), 285-333.

Castle, J.L., Hendry, D.F., 2009. The long-run determinants of UK wages, 1860-2004. Journal of Macroeconomics 31, 5-28.

Catão, L.A.V., Pagan, A., 2011. The credit channel and monetary transmission in Brazil and Chile: a structured VAR approach. In: Céspedes, L.F., Chang, R., Saravia, D. (Eds.), Monetary Policy under Financial Turbulence. Central Banking, Analysis, and Economic Policies Book Series, 16(5), 105-144.

Christiano, L.J., Fitzgerald, T.J., 2003. The band pass filter. International Economic Review $44(2), 435-465$.

Cerrito, E., 2003. Depressioni. Caratteri e genesi delle depressioni di fine XIX secolo, più altre tre (e un'altra ancora). Studi Storici 44(3-4), 927-1005.

Cerrito, E., 2012. Quale storiografia economica? Chiose su «Depressioni». Studi Storici 53(1), 141-191.

Ciccarelli, C., Fenoaltea, S., 2007. Business fluctuations in Italy, 1861-1913: the new evidence. Explorations in Economic History 44, 432-451.

Ciocca, P., 2007. Ricchi per sempre? Una storia economica d'Italia (1796-2005), Bollati Boringhieri, Torino.

Clementi, F., Gallegati, M., Gallegati, M., 2014. Growth and cycles of the Italian economy since 1861: the new evidence. Rivista italiana degli economisti - The Journal of the Italian Economic association, forthcoming.

Cohen, J.S., 1972. The 1927 Revaluation of the Lira: a Study in Political Economy. The Economic History Review 25, 642-654.

Conway, P., Nicoletti, G., 2006. Product Market Regulation in the Non-manufacturing Sectors of OECD Countries: Measurement and Highlights. Working Paper No. 530, Economics

Department,

OECD.

Downloadable

at: 
http://search.oecd.org/officialdocuments/displaydocumentpdf/?cote=eco/wkp(2006)58\& doclanguage $=$ en (last access on December 2013)

Correa-López, M., García-Serrador, A., Mingorance-Arnáiz, C., 2013. Product Market Competition, Monetary Policy Regimes and Inflation Dynamics: Evidence from a Panel of OECD Countries. Oxford Bulletin of Economics and Statistics, 0305-9409. doi: 10.1111/obes.12031.

Daudin, G., Morys, M., O’Rourke, K.H., 2010. Globalization, 1870-1914. In: Broadberry, S.N., O'Rourke, K.H. (Eds.), The Cambridge Economic History of Modern Europe Volume 2. 1870 to the Present. Cambridge University Press, Cambridge, pp. 5-29.

De Bonis, R., Silvestrini, A., 2014. The Italian financial cycle: 1861-2011. Cliometrica 8, 10.1007/s11698-013-0103-5.

Del Boca, A., Fratianni, M., Spinelli, F., Trecroci, C., 2010. The Phillips curve and the Italian lira, 1861-1998. The North American Journal of Economics and Finance 21(2), 182-197.

Del Boca, A., Fratianni, M., Spinelli, F., Trecroci, C., 2012. Macroeconomic instability and the Phillips curve in Italy. Economia Politica - Journal of Analytical and Institutional Economics 29(1), 19-44.

Delli Gatti D., Gallegati M., Gallegati M., 2005. On the Nature and causes of business fluctuations in Italy, 1861-2000. Explorations in Economic History 42, 81-100.

Durré, A., Ledent, P., 2014. Escaping the macroeconomic trilemma: the Belgian two-tier foreign exchange system under Bretton Woods. European Review of Economic History $18(1), 39-56$.

Eichengreen, B., 1987. Conducting the International Orchestra: Bank of England Leadership Under the Classical Gold Standard, 1880-1913. Journal of International Money and Finance 6(1), 5-29.

Eichengreen, B., 2008. Globalizing Capital. A History of the International Monetary System. Second Edition. Princeton University Press, Princeton.

Eichengreen, B., Kenen, P.B., 1994. Managing the World Economy under the Bretton Woods System: An Overview. In: Kenen, Peter B. (Ed.), Managing the World Economy Fifty Years after Bretton Woods, Institute for International Economics, Washington DC, pp. $3-57$.

Elliott, G.T., Rothemberg, J., Stock, J.H., 1996. Efficient tests for an autoregressive unit root. Econometrica 64, 813-836.

Engle, R., 1982. Autoregressive conditional heteroscedasticity with estimates of United Kingdom inflation. Econometrica 50, 987-1008.

Ercolani, P., 1969. Documentazione statistica di base. In: Fuà, G. (Ed.), Lo sviluppo economico in Italia: Studi di settore e documentazione di base, 3. Franco Angeli, Milan, pp. 380-460.

Estevadeordal, A., Frantz, B., Taylor, A.M., 2003. The Rise and Fall of World Trade, 18701939. The Quarterly Journal of Economics 118(2), 359-407.

Federico, G., 1982. Per una valutazione critica delle statistiche della produzione agricola italiana dopo l’Unità (1860-1913). Società e Storia 15, 87-130. 
Federico, G., 2003. Le nuove stime della produzione agricola italiana, 1860-1910: primi risultati ed implicazioni. Rivista di Storia Economica 19, 359-381.

Federico, G., Persson, K.G., 2007. Market Integration and Convergence in the World Wheat Market, 1800-2000. In: Hatton, T.J., O’Rourke, K.H., Taylor, A.M. (Eds.), The New Comparative History: Essays in Honor of Jeffrey G. Williamson. The MIT Press, Cambridge MA, pp. 87-113.

Federico, G., Tena, A., 1998. Was Italy a protectionist country? European Review of Economic History 2(1), 73-97.

Felice, E., Carreras, A., 2012. When did modernization begin? Italy's industrial growth reconsidered in light of new value-added series, 1911-1951. Explorations in Economic History 49 (4), 443-460.

Felice, E., Vecchi, G., 2013. Italy's Growth and Decline, 1861-2011. CEIS Tor Vergata Research Paper Series, Vol. 11, Issue 13, No. 293 - October.

Fenoaltea, S., 1988. International Resource Flows and Construction Movements in the Atlantic Economy: The Kuznets Cycle in Italy, 1861-1913. Journal of Economic History 48, 605-638.

Fenoaltea, S., 2006. L'economia italiana dall'Unità alla Grande Guerra. Laterza, Rome-Bari.

Fenoaltea, S., 2007. The Chemical, Coal and Petroleum Products, and Rubber Industries in Italy, 1861-1913: A Statistical Reconstruction. Rivista di Storia Economica 23(1), 33-80.

Fenoaltea, S., 2011. The Reinterpretation of Italian Economic History. Cambridge University Press, Cambridge.

Ferguson, N., Schularick, M., 2012. The "Thin film of gold": monetary rules and policy credibility. European Review of Economic History 16(4), 384-407.

Filosa, R., Picozzi, L., 2011. I conti nazionali dell'Italia: una rassegna dei principali avanzamenti. Paper presented at "Convegno intermedio, Società Italiana di Statistica".

Findlay, R., O’Rourke, K.H., 2007. Power and Plenty: Trade, War, and the World Economy in the Second Millennium. Princeton University Press, Princeton.

Fisher, I., 1926. A statistical relation between unemployment and price changes. International Labor Review 13, 785-792. (Reprinted as Fisher, I., 1973. I discovered the Phillips curve. Journal of Political Economy 81, 496-502).

Fratianni, M., Spinelli, F., 1984. Italy in the gold standard period, 1861-1914. In: Bordo, M.D., Schwartz, A.J., (Eds.), A Retrospective on the Classical Gold Standard, 18211931. University of Chicago Press, Chicago, pp. 405-454.

Friedman, M., Schwartz, A., 1963. A Monetary History of the United States, 1867-1960. Princeton University Press, Princeton.

Fuhrer, J.C., Moore, G., 1995. Inflation persistence. Quarterly Journal of Economics 110(1), $127-160$.

Galì, J., Gertler, M., 1999. Inflation dynamics: a structural econometric analysis. Journal of Monetary Economics, 44, 195-222.

Giannetti, R., Vasta, M., 2006. Evolution of Italian Entreprises in the 20th Century. Springer, Heidelberg-New York. 
Giordano, C., Giugliano, F., 2014. A tale of two Fascisms: Labour productivity growth and competition policy in Italy, 1911-1951. Explorations in Economic History, http://dx.doi.org/10.1016/j.eeh.2013.12.003.

Giordano, C., Zollino, F., 2014. A Historical Reconstruction of Capital and Labour in Italy, 1861-2013. Banca d'Italia mimeo.

Giugliano, F., 2011. Crisis? Which crisis? New estimates of industrial value added in Italy during the great depression. Mimeo, Bank of Italy.

Godfrey, L.G., 1988. Specification Tests in Econometrics. Cambridge University Press, Cambridge.

Golinelli, R., 1998. Fatti stilizzati e metodi econometrici "moderni": una rivisitazione della curva di Phillips per l'Italia (1951-1996). Politica Economica 3(December), 411-446.

Gordon, R.J., 1981. Inflation, flexible exchange rate, and the natural rate of unemployment. NBER Working Paper No. 708.

Gordon, R.J., 1988. U.S. inflation, labor's share and the natural rate of unemployment. NBER Working Paper No. 2585.

Gordon, R.J., 1990. What is New-Keynesian Economics? Journal of Economic Literature 28 (September), 1115-1171.

Gordon, R.J., 2011. The study of the Phillips curve: consensus and bifurcation. Economica $78,10-50$.

Granger, C.W.J., Jeon, Y., 2011. The evolution of the Phillips curve: a modern time series viewpoint. Economica 78, 51-66.

Hanes, C. (1993). The Development of Nominal Wage Rigidity in the Late $19^{\text {th }}$ Century. American Economic Review, 83, 732-756.

Harvey, A.C., 1985. Trends and cycles in macroeconomic time series. Journal of Business and Economic Statistics 3, 216-230.

Harvey, A.C., Jaeger, A., 1993. Detrending, stylised facts and the business cycle. Journal of Applied Econometrics 8, 231-247.

Henry, S.G.B., Pagan, A., 2004. The econometrics of the New Keynesian policy model: introduction. Oxford Bulletin of Economics and Statistics 66, 581-607.

Hodrick, R.J., Prescott, E.C., 1997. Post-war US business cycles: an empirical investigation. Journal of Money, Credit and Banking 29, 1-16.

Istat (Istituto centrale di statistica), 1957. Indagine statistica sullo sviluppo del reddito nazionale dell'Italia dal 1861 al 1956. Annali di Statistica, Serie 8, vol. 9. Istat, Rome.

Istat (Istituto centrale di statistica), 1973. Annuario di contabilità nazionale. Istat, Rome.

Istat (Istituto centrale di statistica), various years. Annuario statistico italiano. Istat, Rome.

Istat (Istituto centrale di statistica), 2011. Rapporto Annuale. La Situazione del Paese nel 2010. Istat, Rome.

Istat (Istituto centrale di statistica), 2013. Il valore della moneta in Italia dal 1861 al 2012. Istat, Rome. http://www.istat.it/it/archivio/90055 (last access on November 2013). 
James, H., O'Rourke, K.H., 2013. Italy and the First Age of Globalization, 1861-1940. In: Toniolo, G. (Ed.), The Oxford Handbook of the Italian Economy Since Unification. Oxford University Press, Oxford, pp. 37-68.

Kaiser, R., Maravall, A., 1999. Estimation of the Business cycle: A Modified HodrickPrescott Filter. Spanish Economic Review 1, 175-206.

Kiley, M.T., 2013, Output Gaps. Journal of Macroeconomics 37, 1-18.

Klein, L.R., Summers, R., 1966. The Wharton Index of Capacity Utilisation. Wharton School of Finance and Commerce, University of Pennsylvania, Philadelphia.

Ladiray, D., Mazzi, G.L., Sartori, F., 2003. Statistical methods for potential output estimation and cycle extraction. European Commission, Working Papers and Studies.

Mankiw, N.G., 2001. The inexorabile and mysterious tradeoff between inflation and unemployment. The Economic Journal 111(May), C45-C61.

Massman, M., Mitchell, J., 2003. Business Cycles and Turning Points: A Survey of Statistical Techniques. National Institute Economic Review 183, 90-106.

Mills, T.C., Crafts, N.F.R., 1996. Modelling trends in economic history. Journal of the Royal Statistical Society, series D (The Statistician) 45(2), 153-159.

Morley, J.C., Nelson, C.R., Zivot, E., 2003. Why are the Beveridge-Nelson and unobservedcomponents decompositions of GDP so different? The Review of Economics and Statistics 85(2), 235-243.

Newey, W.K., West, K.D., 1987. A simple, positive semidefinite, heteroskedasticity and autocorrelation consistent covariance matrix. Econometrica 55(3), 703-708.

O'Rourke, K.H., Williamson, J.G., 1994. Late $19^{\text {th }}$ Century Anglo-American Factor Price Convergence: Were Heckscher and Ohlin Right? Journal of Economic History 54(4), 892-916.

Phillips, A.W., 1958. The relation between unemployment and the rate of change of money wage rates in the United Kingdom. Economica 25, 283-299.

Pistoresi, B., Rinaldi, A., 2012. Exports, imports and growth. New evidence on Italy: 18632004. Explorations in Economic History 49(2), 241-254.

Ravn, M.O., Uhlig, H., 2002. On adjusting the Hodrick-Prescott filter for the frequency of observations. Review of Economic Studies 84(2), 371-380.

Rey, G.M., Ed., 2000. I conti economici dell'Italia. 3**. Il valore aggiunto per gli anni 1891, 1938, 1951. Laterza, Rome-Bari.

Rossi, N., Toniolo, G., 1992. Catching up or Falling Behind? Italy's Economic Growth, 18951947. The Economic History Review 45(3), 536-563.

Rossi N., Sorgato, A., Toniolo, G., 1993. I conti economici italiani: una ricostruzione statistica: 1890-1990. Rivista di Storia Economica 10, 1-47.

Rossi, N., Toniolo, G., 1996. Italy. In: Crafts, N., Toniolo, G. (Eds.), Economic Growth in Europe since 1945. Cambridge University Press, Cambridge, pp. 427-454.

Rota, M., 2013. Credit and growth: reconsidering Italian industrial policy during the Golden Age. European Review of Economic History 17(4), 431-451. 
Rudd, J., Whelan, K., 2005. New tests of the New-Keynesian Phillips curve. Journal of Monetary Economics 52, 1167-1181.

Rudd, J., Whelan, K., 2007. Modeling inflation dynamics: a critical review of recent research. Journal of Money, Credit and Banking 39(1), 155-170.

Sachs, J., 1980. The changing cyclical behavior of wages and prices: 1890-1976. American Economic Review 70(1), 78-90.

Sella, L., Marchionatti, R., 2012. On the cyclical variability of economic growth in Italy, 1881-1913: a critical note. Cliometrica 6(3), 307-328.

Shibamoto, M., Shizume, M., 2014. Exchange rate adjustment, monetary policy and fiscal stimulus in Japan's escape from the Great Depression. Explorations in Economic History, http://dx.doi.org/10.1016/j.eeh.2014.02.002.

Sims, C.A., 1987. Comment. Brooking Papers on Economic Activity 1, 117-120.

Sleeman, A.G., 2011. The Phillips Curve: A Rushed Job? Journal of Economic Perspectives 25(1), 223-238.

Stock, J.H., Watson, M.W., 1999. Forecasting inflation. Journal of Monetary Economics 44, 293-335.

Stock, J.H., Watson, M.W., 2007. Why Has U.S. Inflation Become Harder to Forecast? Journal of Money, Credit and Banking 39(1), 3-33. 


\section{Appendix A1. The methodological heterogeneity of Italy's national accounts historical data}

\section{Introduction}

The reconstruction of historical data over a period as long as the one stretching from the foundation of the Italian state in 1861 to date involves the need to resort to sources whose degree of sectoral detail, and whose intrinsic quality, change over time often implying a methodological break in the series. Such heterogeneity should be taken into account in quantitative analysis, for instance when using the GDP time series to estimate the output gap, as done in this paper. The purpose of this appendix is simply to inform the reader on the main elements of heterogeneity of the new national accounts data, presented in Baffigi (2013).

First of all, there is an important watershed: before and after the 1950s. In 1973, the Italian statistical Office published a time series for supply and uses, at current and constant prices, for the period 1951-1972 (ISTAT, 1973). The GDP growth rates provided by this time series were used to interpolate the two benchmarks at current prices for 1951, reconstructed by the group coordinated by Guido Rey (2000), and for 1970, provided by the official Istat data. The constant price data for the period 1951-1970 were obtained using the implicit deflators of ISTAT (1973). Overall, the period 1951-2012 is characterized by some methodological heterogeneity, which is mainly due to the progressive improvement of statistical production: a significant acceleration towards a more modern statistical approach was launched during the $1980 \mathrm{~s}$, when the quality and reliability of the data further improved (Filosa and Picozzi, 2011). However, the ensuing changes have a much lower order of magnitude compared to those which took place in 1951, as well as those which occurred within the first ninety years of Italy's history, up to 1911. The latter are discussed in the remainder of this Appendix.

\section{$1861-1911$}

In the first fifty years of political unity, 1861-1911, a national statistical system was gradually built. Many surveys were performed but they were often fragmented and unreliable, especially in the early post-unification years. Against this background, Stefano Fenoaltea's work can be set: he carried out critical analysis of quantitative sources and produced a time series, covering the period 1861-1913, for the value added of 200 industrial products, grouped into 15 sectors. Fenoaltea published approximately fifty papers (articles and essays) ${ }^{37}$. Italy's industrial value added from 1861 to 1913 was reconstructed with such fine sectoral details, probably unique in the international economic history literature.

Also the methodological issues related to agricultural value added have interesting implications: the old series, which was reconstructed by Istat (1957) and was substantially adopted by Ercolani (1969), was carefully analysed by Giovanni Federico (1982, 2003), who underlined the inadequacy and unreliability of Istat series (especially in relation to the 1880s:

\footnotetext{
${ }^{37}$ A partial list of such papers, as of 2011, can be found in Fenoaltea (2011). While waiting for the author to publish the Summa of several decades of his work - that is the unpublished Italian Industrial Production: 18611913. A Statistical Reconstruction - scholars should refer to the numerous published essays which cover a substantial part of the author's work.
} 
a controversial decade when, based upon the old data, an agrarian crisis occurred due to a sharp fall in the prices of imported grain). ${ }^{38}$

More recently, Battilani, Felice and Zamagni (2011) reconstructed a time series at current prices for the value added of the major services sectors. Their sources, often adjusted by interpolation or extrapolation, were used also by Baffigi $(2011,2013,2014)$ and Brunetti (Brunetti et al., 2011) to reconstruct the series at constant prices.

Overall, the new GDP series provide a paradigm shift in the interpretation of the Italian economic development. The old data pointed to a prolonged stagnation which gave way to an acceleration from the end of the 1890s throughout the Giolittian era (1900-1914). Instead, the new reconstruction of agriculture value added, together with that of industry and services, for the period 1861-1911, leads to exclude the possibility of a sudden take-off (a big spurt), from the late nineteenth century to the First World War. The new view, especially thanks to Fenoaltea's and Federico's data which are incorporated in Baffigi's national account data (2011) point to a gradual expansion of the production, which occurred since the 1880s, albeit characterized by an acceleration in the last fifteen years before the First World War. On this background, Ciccarelli and Fenoaltea (2007, p. 437) point out that "the immediate aim [of the new series] was to remove the gross errors displayed over the medium and long term by the extant Istat-Vitali series and their subsequent derivatives; and this much they appear to have achieved."

From the methodological point of view, potentially the major problem is posed by the agricultural sector, for which in the liberal age we now have both a less pronounced cyclical variation and a less detailed sectoral decomposition than with Istat's and Ercolani's previous figures. The objective pursued by Federico (2003) was to reconstruct "annual series of the production of agriculture, forestry and fisheries at national and regional level from 1861 to 1938 and then to connect the new time series to ISTAT series for the years after World War II" (Federico, 2003). Federico's research provides a valuable progress towards an ambitious goal, but it is still to be considered "far behind" (Federico, 2003, p. 376): the author himself stresses the preliminary nature of his series which would require some changes, for instance aimed at making finer sectoral analysis. In particular, further work is needed in order to take more products into consideration: "all minor agricultural products, forestry and fishing (which represent about a third of the total production ) are lacking"; expenses should be estimated "to calculate the value added; the dependence of agricultural production on weather conditions should be taken into account" (Federico, 2003, pp. 364 and ff.). In order to have an idea of the impact of agriculture on GDP, it is useful to mention that in the new data the weight of the total agricultural value added ranges from 45 percent in 1861 to 40 percent in 1911. On this issue, however, unreported results (available upon request) are strongly reassuring. In fact, our findings do not change if we add the cyclical component of Ercolani's value added in agriculture (1969) to the trend component of Federico's data (2003), for the years 1861 to 1913. Interestingly, based on this more cyclical artificial GDP, we substantially obtained the same outcome as with Federico's series (i.e. no inflation-out gap trade-off).

$$
1911-1951
$$

\footnotetext{
${ }^{38}$ It is fair to acknowledge, however, that the debate concerning this aspect is still open: Cerrito (2003, 2012), by relying upon new information and historical sources, argues in favour of the existence of the agrarian crisis, and questions the reliability of both Fenoaltea's and Federico's estimates. The two views are not irreconcilable. However, the agrarian crisis may have hit some areas and sectors of the Italian economy (the agricultural day labourers in the South) not necessarily resulting in a reduction of total output.
} 
In the second time segment of the new historical data of national accounts, the quality and quantity of statistical sources increased significantly compared to the previous period. This is true primarily for agriculture, whose data benefit from the reorganization of the agricultural statistics of 1907-1909 (Federico, 2003, p. 364). This is partly true also for industry and for services.

As regards industry, it is important to stress that the new series for the 1911-1951 years innovate substantially compared to the series by Ercolani (1969). In particular, they reproduce the results of the cited work by Carreras and Felice (2010), as revised by Giugliano (2011), whose time profile is indeed very different from the old series and, importantly, is based on a rather high number of elementary series. From a historical point of view, Felice and Carreras's new series introduce an important change in the industrial activity as regards the Great War, which is no longer characterized by the acceleration displayed by the old series. That acceleration resulted in an abnormal profile compared to the main European countries (Felice and Carreras, 2012, pp. 447-448), an important issue that had been acutely noticed by Broadberry (2005). ${ }^{39}$ Giugliano's work, on the other hand, provided a new view of the great crisis in Italy, which is now deeper and longer than previously documented, much more in line with all other industrialized countries.

Overall, Carreras and Felice (2010) and Giugliano (2011) reconstructed a time series for about 90 industrial products: not few compared to the early work of Gerschenkron, a number comparable to that available for other countries, and yet less than half the time series estimated by Fenoaltea for the 1861-1913 period. ${ }^{40}$ Felice and Carreras (2012) extended their reconstruction beyond the 1938 benchmark, until 1951, reclaiming, in fact, also those methodologically dark thirteen years which were based on the old Ercolani (1969) series. The series used here are those presented in Baffigi (2011), only updated to reflect the latest data published by ISTAT, and do not take into account such work; in fact, for the years 1938-1951 the differences between the new and the old series are minimal.

In the previous series by Ercolani (1969) for 1911-1951- - which was widely considered of dubious methodological soundness - the less details available for industry could spuriously induce higher variability in the GDP series, resulting from the fact that a relatively smaller number of series is attributed the burden "to represent a much larger whole, in effect overstating cyclical variations by assuming perfect positive correlations even where these were more plausibly limited or even negative" (Ciccarelli and Fenoaltea, 2007, pp. 436-437). With the new Carreras, Felice and Giugliano's series, much more numerous, it becomes more difficult to attribute the different cyclical variability of industrial value-added which characterizes the two periods (1861-1911 and 1911-1951) to methodological artifacts rather than to well-documented historical events (the two World Wars and the 1929 crisis).

\footnotetext{
${ }^{39}$ Also the new series on services (Battilani et al., 2011) contribute to more plausible movements in GDP over the First World War, in the international perspective adopted in Broadberry (2005)'s analysis.

${ }^{40}$ For the first few decades after the political unification, however, the quality and availability of data are rather weak and poor. For example, the 80 series estimated for the chemical industry "for the early decades are extensively interpolated" (Fenoaltea, 2007 Note (b) to Table 1).
} 


\section{Appendix A2. Extracting potential output and the output gap from GDP}

Let's assume that $y_{t}$ (i.e. the time series of GDP log-levels in volume) can be decomposed as:

$$
y_{t}=\tau_{t}+\delta_{t} \quad \text { with } \mathrm{t}=1,2, \ldots, \mathrm{T}
$$

where $\tau_{t}$ is the GDP permanent component (i.e. the potential output in logs); $\delta_{t}$ is the transitory component of GDP or output gap measuring the log-deviations of actual output from potential output.

We estimate nine output gap measures as $\hat{\delta}_{t}=y_{t}-\hat{\tau}_{t}$, according to the alternative nine ways we used to estimate $\hat{\tau}_{t}$. These techniques are explained in the three sections below, which summarize alternative methodological approaches labelled as: "segmented trends", "filters and univariate decompositions", and "models with unobservable components". Reviews of these approaches are in Ladiray et al. (2003), and in Massman et al. (2003); Kiley (2013) compares statistical and structural approaches to estimate output gaps. Further details and statistical evidence of what is condensed in this appendix are given in Baffigi et al. (2013, sections 2 and 3 ).

\section{Segmented trends: PTPT, STOLS, BP}

The model with segmented trends assumes that the growth rate of potential output in equation (A1) is piecewise constant within the $i$ subperiods $(i=1,2, \ldots ., \mathrm{S})$ making up the sample:

$$
\tau_{t}=\sum_{i=1}^{S} \alpha_{i} D_{i}+\sum_{i=1}^{S} \beta_{i} D_{i} t
$$

where $\alpha_{i}$ is the constant coefficient of the linear model to be estimated within each subperiod $i ; D_{i}$ is a dummy variable equal to one in the $\mathrm{i}^{\text {th }}$ period, zero otherwise; $t$ is a linear trend; and finally, the parameter $\beta_{i}$ measures the average growth of potential output in the $\mathrm{i}^{\text {th }}$ segment (slope of the trend). In (A2) the potential output is assumed to move linearly within each cycle (constant growth), while it is free to change from one cycle to another. Substituting (A2) in (A1) we obtain the specification of the model with segmented trends:

$$
y_{t}=\sum_{i=1}^{S} \alpha_{i} D_{i}+\sum_{i=1}^{S} \beta_{i} D_{i} t+\delta_{t}
$$

where $\delta_{t}$ is the output gap. Simple and easy to implement, the segmented trends approach warrants immediate and direct application to data, given an official calendar dating the cycle. The precursors of this method, often referred to as the "NBER approach", are Burns and Mitchell (1946). Since then, this approach has often been used in the literature (see, among others, the applications of Friedman and Schwartz, 1964, and Klein and Summers, 1966).

The main ingredient of potential GDP and output gap estimate with segmented trends is the prior knowledge of the ends of each segment $i$, i.e. the date on which the break of the linear trend might have occurred; or, in other words, the date on which a supply shock might have permanently changed the potential output growth. Such important points in time may be known a priori, or identified by purely statistical procedures.

The "Wharton" method of the peak-to-peak trend (PTPT) of Klein and Summers (1966) is the classic way in which the equation (A3) has been implemented historically. The PTPT 
method is a special case of segmented trend with known dates: it is based on the assumption that the break dates coincide with the succession of peaks of economic cycles that occurred over the sample period, and each segment interpolates two points ranging from the year after there was a peak of the cycle until the year in which the following peak occurs. Since the application of the PTPT method provides no procedure for statistical estimation and inference, it is purely deterministic.

Alternatively, still based on an a priori knowledge of the break dates, parameters $\alpha_{i}$ and $\beta_{i}$ can be estimated by minimizing $\sum_{t=1}^{T} \hat{\delta}_{t}^{2}$, i.e. by OLS estimation of the parameters of equation (A3). This segmented trends estimation approach (STOLS) implies the minimization of the cycle (output gap) variability.

Even if both PTPT and STOLS are related to the same model (A3), the STOLS method - contrary to PTPT - allows a recursive testing of the statistical significance of the change in the constant and in the slope coefficients of the trend function in the transition from the $i^{\text {th }}$ segment to the next.

We applied both PTPT and STOLS techniques, under the assumption that the a priori known dates of the cyclical peaks coincide with the dates of breaks in the trend function of potential output. The need for a priori dates of the cyclical peaks from 1861 to 2010 clashes, in the Italian case, with the absence of empirical studies on the economic cycle bearing the mark of one or more authoritative institutions and designed specifically to provide guidance on the dates of the cyclical phases of the Italian economy (see e.g. the NBER calendar for the US). Therefore, the cyclical peaks used here were identified on the basis of the chronology in Box 1 and Table 1 of Baffigi et al. (2013), who put together the outcomes in: Carreras and Felice (2010, 2012), Ciccarelli and Fenoaltea (2007), Delli Gatti, Gallegati and Gallegati (2005), Ercolani (1975), Fenoaltea (2006), Giugliano (2011), ISTAT (2001, 2011), and Rossi, Toniolo and Sorgato (1993).

Alternatively, assuming that the timing of the break is unknown a priori, it can be estimated with testing procedures applied to the model (A3). Bai and Perron (1998 and 2003, henceforth BP) propose an algorithm based on the principle of dynamic programming, aimed at the efficient global minimization of the sum of squared residuals of model (A3), where the unknown multiple breaks dates are estimated along with parameters $\alpha_{i}$ and $\beta_{i}$. The resulting break dates correspond to the partition of the sample that minimizes the Bayesian Information Criterion among all possible alternative points of break away from each other for more than a minimum number of years (in our case, 8 years).

\section{Filters and univariate decompositions, HP100, HP625, BK, CF, BN}

The HP filter, Hodrick and Prescott (1997), is the most commonly used approach in literature to extract the trend component (potential output) from GDP data; its appeal is mainly due to its conceptual simplicity. The HP filter estimates the potential output series as the solution of a minimization problem:

$$
\min \sum_{t=1}^{T}\left[\left(y_{t}-\tau_{t}\right)^{2}+\lambda\left(\Delta \tau_{t+1}-\Delta \tau_{t}\right)^{2}\right]
$$

that, given the definition (A1) above, can be rewritten as $\min \sum_{t=1}^{T}\left[\delta_{t}^{2}+\lambda\left(\Delta^{2} \tau_{t+1}\right)^{2}\right]$, where $\lambda$ is the key parameter of the HP filter, as it determines the relative importance of demand shocks (cyclical effects in $\delta_{t}$ ). We alternatively set $\lambda=100$ (as suggested in the 
Hodrick-Prescott paper, HP100), and $\lambda=6.25$ (as suggested in Ravn and Uhlig, 2002, HP625).

Some weaknesses of the HP filter have stimulated the literature to introduce alternative filters and decomposition techniques. Among others, we used the two band-pass filters of Baxter and King (1999, BK), and of Christiano and Fitzgerald (2003, CF).

As final alternative, we took into consideration the GDP decomposition of Beveridge and Nelson (1981, BN). The BN approach, particularly suited for I(1) time series, ${ }^{41}$ has the merit of recognizing the stochastic nature of the decomposition problem, although at the cost of very sensitive results to the choice of the specification of the ARIMA model on which it is based.

\section{Models with unobservable components: UCMLT}

Since the seminal Harvey (1985), the decomposition techniques of trend and cycle models with unobservable components (UCM) are applied in the literature even for very long time spans; see Mills and Crafts (1996), and Fenoaltea and Ciccarelli (2007). Compared to BN decomposition, the UCM approach has the advantage of modelling all the components of interest jointly, treating them as independent stochastic processes, without the need to make assumptions on how to transform the data to make them stationary.

The UCM approach of modelling the potential output resumes definition (A1), then explicitly assumes that trend $\tau_{t}$ and cycle $\delta_{t}$ are independent stochastic components, that is to say: $E\left(\tau_{t} \delta_{s}\right)=0$ for all $\mathrm{t}$ and $\mathrm{s}$. On the basis of Harvey and Jaeger (1993), the stochastic trend $\tau_{t}$ is modelled as a local linear trend process (labelled as UCMLT):

$$
\begin{aligned}
& \tau_{t}=\tau_{t-1}+\beta_{t-1}+\eta_{t} \\
& \beta_{t}=\beta_{t-1}+\xi_{t}
\end{aligned}
$$

where the stochastic process $\beta_{t}$ indicates the trend slope ${ }^{42}$ and the stochastic terms $\eta_{t}$ and $\xi_{t}$ are independent from each other and are extracted from i.i.d. normal distributions with variance equal to $\sigma_{\eta}^{2}$ and $\sigma_{\xi}^{2}$, respectively. ${ }^{43}$

Depending on the values assumed by the UCMLT parameters (including the variances), different specific models emerge to account for alternative dynamics of growth and different forms of structural break. ${ }^{44}$ The estimate of the unobservable components of the

\footnotetext{
${ }^{41}$ For a discussion and a comparison of the implications deriving from the use of the filters HP and BN for estimating the permanent component of the output gap, see Catão and Pagan (2011). In particular, the authors stress that, based on the analysis in Harvey and Jaeger (2003), the HP filter extracts I(2) permanent components; hence, in the presence of I (1) series, the BN filter is more appropriate.

${ }^{42}$ The comparison of (A5) with (A2) shows the deterministic (and a priori) nature of the discrete changes of $\beta_{i}$ in (A2) if contrasted with the constant fluctuations in the causal variable $\beta_{t}$ allowed by (A5).

${ }^{43}$ Morley et al (2003) study and compare the BN and UCM in a common methodological context, and conclude that the difference in the results obtained by the two methods is attributable to the UCM assumption of no correlation between trend and cycle shocks.

${ }^{44}$ If unrestricted, the trend representation (A5) corresponds to a second-order integrated ARIMA. If $\sigma_{\eta}^{2}=\sigma_{\xi}^{2}=$ 0 , the model becomes purely deterministic; if only $\sigma_{\xi}^{2}=0$, the trend is a random walk (i.e. first-order integrated). If, finally, only $\sigma_{\eta}^{2}=0$, the model is second-order integrated with persistent and smoothed dynamics, and second-differences equal to a purely random process.
} 
model combining (A1) and (A5) requires a state-space specification with the vector of not observable variables $\tau$ and $\beta$ explained by the state equations (A5), and GDP (i.e. the only observable variable) explained by the measurement equation (A1). The estimation of the model is performed by maximizing the likelihood function via the Kalman filter that provides a recursive estimation of the vector of state variables for each $t$, conditional to all available information.

\section{Appendix A3. A summary of the Italian output gap trough PCA}

Our different nine measures of business cycle can be summarized through the factor representation of the $n$-dimensional vector $X_{t}$ (where $n=9$ is the number of our output gap measures) for the t-th observation. This technique (Principal Components Analysis, PCA) defines the following relationship:

$$
X_{t}=\Lambda f_{t}+u_{t}
$$

where $f_{t}$ is the vector of the $r$ factors $(r<\mathrm{n}$, we assume $\mathrm{r}=1)$, not observable variables that influence the fluctuations of all observable variables (the nine alternative output gaps) included in the matrix $X_{t}, \Lambda$ is the $(\mathrm{n} \times \mathrm{r})$ matrix of loadings, parameters that convert factors in observable measures; $u_{t}$ are the idiosyncratic shocks of the individual measures. The basic idea in equation (A6) is that few (in our case, only one) common factors may cause the comovements between the available measures of the output gap. In order to better disentangle the information of interest, this approach extracts the signal $f_{t}$ and, consequently, isolates the noise.

By applying PCA, the factors can be estimated from $\hat{f}_{t}=\hat{\Lambda}^{\prime} X_{t}$, where $\hat{\Lambda}$ is made up of the first $r$ eigenvectors of the $n \times n$ dimensional matrix $\hat{\Sigma}_{X X}=T^{-1} \sum_{t=1}^{T} X_{t} X_{t}^{\prime}$. Intuitively, the stronger the covariance is between the $n$ variables of interest, the greater the share of the total variability that can be explained by only few factors.

Table A2.1 presents main results from PCA. In order to assess the consistency of the results over time, outcomes are reported - along the columns - for the three sub-periods and for the whole period. It turns out that, with only the first principal component, model (A6) explains about $70 \%$ of the total variability of the measures of output gap in $X_{t}$.

\section{Table A2.1 here}

Such a high proportion of overall variability explained by a single component suggests that the correlation between the nine output gap measures is so high that their prominent information may be synthesized by just one time series, $f_{t}$.

It is also important to notice that, in the light of such clear-cut results, the number of components to be estimated according to the methods usually followed in the literature (for example, the vision of the scree plots, i.e. the diagram of the sorted eigenvalues) would be the same (i.e. one). In fact, the marginal benefit in terms of share of total variability explained by adding another component is fairly constant from the second eigenvalue onwards and would not lead to significant increases in the explanatory power of factors' synthesis.

The lower part of Table A2.1 reports the first eigenvector for each sample period. The weights of the nine output gap measures used for the estimation of the first principal component are very similar to each other, and tend to be constant in the different sub-periods 
of analysis. Nevertheless, in order to test the robustness of the results, we estimated the first principal component, ${ }_{1} \hat{f}_{t}^{j}$ in two alternative ways: (1) $j=1$ indicates that the component is obtained by using the three factor estimates specific of each sub-period; $j=2$ indicates that the component is obtained by using the single factor estimate over the whole period. 


\section{Tables and Figures}

Tab. 1 - Yearly growth rates of output, productivity and prices, by sub-periods ${ }^{a}$

\begin{tabular}{lrrrrrrr}
\hline & Output & Productivity & TFP & GDP deflator & PC deflator & M deflator & CLI \\
$1861-1913$ & 1.58 & 0.89 & 0.00 & 0.45 & 0.33 & -0.66 & 0.38 \\
$1861-1895$ & 1.23 & 0.72 & -0.02 & -0.13 & -0.34 & -1.76 & 0.25 \\
$1895-1913$ & 2.25 & 1.22 & 0.09 & 1.55 & 1.60 & 1.43 & 0.64 \\
$1914-1938$ & 1.72 & 0.85 & 0.73 & 6.73 & 6.86 & 6.03 & 6.31 \\
$1922-1938$ & 2.34 & 1.65 & 0.85 & -0.18 & -0.41 & -1.02 & -0.30 \\
$1922-1929$ & 4.11 & 3.09 & 2.96 & -0.02 & -0.49 & -0.95 & 1.02 \\
$1929-1938$ & -0.98 & 0.54 & -0.64 & -0.31 & -0.35 & -1.08 & -0.25 \\
$1951-2012$ & 3.10 & 2.35 & 0.52 & 6.09 & 6.01 & 4.53 & 5.81 \\
$1951-1973$ & 5.84 & 4.42 & 1.33 & 4.14 & 3.87 & 0.95 & 3.87 \\
$1973-1992$ & 2.72 & 1.92 & 0.41 & 12.59 & 12.27 & 10.46 & 11.96 \\
$1992-2012$ & 0.64 & 0.60 & -0.23 & 2.51 & 2.82 & 3.13 & 2.50 \\
$1861-2012$ & & & & & & &
\end{tabular}

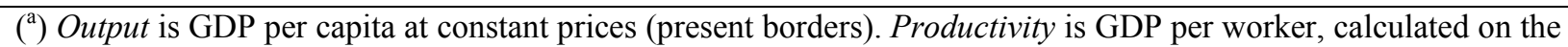
full-time equivalent workers (Broadberry et al., 2011). TFP is total factor productivity, estimated from a standard growth accounting exercise (Solow's residuals), as the difference between output growth and the weighted average of the growth rates of factor inputs (labor and capital); the weighted average has been calculated using the wage share in GDP (wage data are from Giordano and Zollino, 2014), smoothed with Hodrick and Prescott (1997) filter with $\lambda=100$ (HP100); data on employment and capital stocks from Broadberry et al. (2011). GDP deflator is the deflator of GDP, $P C$ deflator is the deflator of private consumption, $M$ deflator is the deflator for the imports of goods and services; all deflators are obtained as ratios of current prices to constant prices, for further details see Baffigi (2013, pp. 175-183); CLI is the cost of life index, i.e., the Istat "index of consumer prices for families of blue- and white-collar workers" (Istat, 2013). 


\section{periods: $\quad 1864-2012 a \quad 1864-1913 \quad 1914-1938$}

$1951-2012$

First-differences of logdeflators of:

$b$

$G D P$

DF-GLS $c$

ar1 $d$

ar2 $d$

$\mathrm{AC}(2)^{e}$

$\operatorname{ARCH}(2) f$

$\mathrm{R}^{2}$

$\hat{\sigma} g$

Private consumption

DF-GLS $c$

ar1 $d$

ar2 $d$

$\mathrm{AC}(2)^{e}$

$\mathrm{ARCH}(2) f$

$\mathrm{R}^{2}$

$\hat{\sigma}^{g}$

Imports of goods and services

DF-GLS $c$

ar1 $d$

ar2 $d$

$\mathrm{AC}(2)^{e}$

$\mathrm{ARCH}(2) f$

$\mathrm{R}^{2}$

$\hat{\sigma} g$

Cost of life index

DF-GLS ${ }^{c}$

ar1 $d$

ar2 $d$

$\mathrm{AC}(2)^{e}$

$\operatorname{ARCH}(2) f$

$\mathrm{R}^{2}$

$\hat{\sigma} g$

\begin{tabular}{|c|c|c|}
\hline-2.761 & $* * *$ & -5.065 \\
\hline 0.700 & $* * *$ & 0.234 \\
\hline-0.015 & & -0.483 \\
\hline 0.596 & & 0.248 \\
\hline 24.420 & $* * *$ & 1.410 \\
\hline 0.479 & & 0.253 \\
\hline 0.057 & & 0.043 \\
\hline
\end{tabular}

0.057

$\begin{array}{rr}-4.198^{* * *} & -5.352^{* * *} \\ 0.648^{* * *} & 0.186 \\ -0.176^{* *} & -0.479 \\ 1.149^{* * *} & 0.238 \\ 24.954^{* * *} & 1.524 \\ 0.325^{* *} & 0.241 \\ 0.091 & 0.046\end{array}$

$-3.924^{* * *} \quad-2.675^{* * *}$

$0.466^{* * *}$

0.151

$-0.050$

$4.714^{* *}$

26.942

0.197

0.116

$-0.163$

0.003

0.195

0.043

0.047

$\begin{array}{rr}-2.737^{* * *} & -5.716^{* * *} \\ 0.599^{* * *} & 0.079 \\ 0.060 & -0.162 \\ 3.256^{*} & 0.203 \\ 18.758^{* * *} & 0.429 \\ 0.412^{*} & 0.031 \\ 0.055 & 0.038\end{array}$

$-1.179$

$\begin{array}{rr}-2.096^{* *} & -1.179 \\ 0.675^{* * *} & 1.060^{* * *} \\ 0.015 & -0.160 \\ 0.284 & 0.902^{* * *} \\ 1.673 & 5.063^{* *} \\ 0.475 & 0.832 \\ 0.105 & 0.021\end{array}$

$-2.751^{* * *} \quad-1.462$

$0.628^{* * *} \quad 1.074$

$-0.215$

$-0.194$

0.929

5.674

0.813

0.022

$0.200 \quad 0.022$

$\begin{array}{rr}-1.845^{*} & -0.431 \\ 0.474^{* *} & 0.428 \\ -0.136 & 0.102 \\ 0.829 & 3.304^{* *} \\ 3.400^{*} & 2.369 \\ 0.183 & 0.237 \\ 0.237 & 0.083\end{array}$

$\begin{array}{rr}-1.697^{*} & -0.053 \\ 0.598^{* *} & 0.746^{* * *} \\ -0.048 & 0.117 \\ 0.368 & 1.838 \\ 0.967 & 1.035 \\ 0.330 & 0.741 \\ 0.107 & 0.026\end{array}$

$\left(^{a}\right)$ The whole period excludes the $1939-1950$ period. $\left({ }^{b}\right)^{* * *},{ }^{* *}$ and ${ }^{*}$ mark rejections at $1 \%, 5 \%$ and $10 \%$ level of significance of the corresponding tests. $\left({ }^{c}\right)$ DF-GLS (Elliott et al, 1996) test statistic in a model with constant and no trend; lag order selected by MAIC (Modified AIC) criterion of Ng and Perron (2001) starting from a maximum of 3 lags. $\left({ }^{\mathrm{d}}\right)$ arl and ar2 are the estimates of the AR(2) model parameters. $\left({ }^{\mathrm{e}}\right)$ Test statistic for second-order autocorrelation of the residuals of the AR(2) model; Godfrey (1988). $\left(^{f}\right)$ Test statistic for secondorder autoregressive conditional heteroscedasticity of the AR(2) model residuals; Engle (1982). $\left({ }^{g}\right)$ Standard error of the regression of the AR(2) model. 
Table A2.1 - Principal Component Analysis of the gap measures

Periods: $\quad 1864-1913 \quad 1914-1938 \quad 1951-2012 \quad 1864-2012 a$

Cumulated share of total variance explained by the i-th component $b$ $\mathrm{i}=$

$\begin{array}{lllll}1 & 0.6999 & 0.6599 & 0.6207 & 0.6376 \\ 2 & 0.8034 & 0.7675 & 0.7786 & 0.7489 \\ 3 & 0.8903 & 0.8535 & 0.8581 & 0.8298 \\ 4 & 0.9414 & 0.9184 & 0.9147 & 0.8997 \\ 5 & 0.9739 & 0.9623 & 0.9564 & 0.9487 \\ 6 & 0.9886 & 0.9927 & 0.9812 & 0.9778 \\ 7 & 0.9963 & 0.9990 & 0.9960 & 0.9968 \\ 8 & 0.9997 & 0.9999 & 0.9996 & 0.9994 \\ 9 & 1.0000 & 1.0000 & 1.0000 & 1.0000\end{array}$

Estimate of the first eigenvector in $\hat{\Lambda} c$

$\begin{array}{cllll}\text { PTPT } & 0.3265 & 0.2264 & 0.3475 & 0.2735 \\ \text { ST-OLS } & 0.2590 & 0.3059 & 0.2529 & 0.2754 \\ \text { BP } & 0.3331 & 0.3330 & 0.3417 & 0.3440 \\ \text { BN } & 0.2692 & 0.3037 & 0.1350 & 0.2271 \\ \text { UCMLT } & 0.2436 & 0.2429 & 0.2788 & 0.2505 \\ \text { HP100 } & 0.3731 & 0.3657 & 0.3737 & 0.3741 \\ \text { HP625 } & 0.3874 & 0.4025 & 0.4072 & 0.4079 \\ \text { BK } & 0.3918 & 0.4033 & 0.4080 & 0.4089 \\ \text { CF } & 0.3751 & 0.3669 & 0.3615 & 0.3783\end{array}$

(a) The whole period 1864-2012 is the union of the three sub-periods, excluded the years from 1939 to 1950. (b) Measured as the ratio of each eigenvalue of $\hat{\Sigma}_{X X}=T^{-1} \sum_{=1}^{T} X_{t} X_{t}^{\prime}$ matrix (in decreasing order) over the total (which is the number of variables, $n=9$ ). ( ${ }^{c}$ ) First eigenvector of the $\hat{\Sigma}_{X X}$ matrix. 
Table 3 - GMM estimates of alternative hybrid Phillips curve in subsamples ${ }^{a}$

\begin{tabular}{|c|c|c|c|c|c|c|c|c|c|c|c|c|c|c|c|c|c|c|c|c|c|c|}
\hline & \multicolumn{6}{|c|}{$1864-1913$} & \multicolumn{8}{|c|}{ 1914-1938 } & \multicolumn{8}{|c|}{$1951-2012$} \\
\hline & (1) & & (2) & & (3) & & (4) & & (5) & & (6) & & (7) & & (8) & & (9) & & (10) & & (11) & \\
\hline$\alpha_{0}$ & $\begin{array}{l}\mathbf{0 . 0 0 2 1} \\
0.0046\end{array}$ & & $\begin{array}{l}\mathbf{0 . 0 0 0 2} \\
0.0034\end{array}$ & & $\begin{array}{l}\mathbf{0 . 0 0 6 2} \\
0.0044\end{array}$ & & $\begin{array}{r}\mathbf{- 0 . 0 0 0 5} \\
0.0054\end{array}$ & & $\begin{array}{l}\mathbf{0 . 0 0 4 4} \\
0.0034\end{array}$ & & $\begin{array}{l}\mathbf{0 . 0 0 0 8} \\
0.0068\end{array}$ & & $\begin{array}{l}\mathbf{0 . 0 1 6 5} \\
0.0131\end{array}$ & & $\begin{array}{l}\mathbf{0 . 0 0 4 0} \\
0.0019\end{array}$ & * & $\begin{array}{l}\mathbf{0 . 0 0 0 3} \\
0.0013\end{array}$ & & $\begin{array}{r}\mathbf{- 0 . 0 0 0 6} \\
0.0020\end{array}$ & & $\begin{array}{l}\mathbf{0 . 0 0 3 3} \\
0.0021\end{array}$ & \\
\hline$\alpha_{f}$ & $\begin{array}{l}\mathbf{0 . 6 8 5 6} \\
0.1741\end{array}$ & $* * *$ & $\begin{array}{l}\mathbf{0 . 7 8 6 8} \\
0.0746\end{array}$ & $* * *$ & $\begin{array}{l}\mathbf{0 . 4 2 8 1} \\
0.2277\end{array}$ & * & $\begin{array}{l}\mathbf{0 . 6 1 3 7} \\
0.0871\end{array}$ & $* * *$ & $\begin{array}{l}\mathbf{0 . 5 7 6 1} \\
0.0727\end{array}$ & $* * * *$ & $\begin{array}{l}\mathbf{0 . 4 5 3 9} \\
0.0594\end{array}$ & $* * *$ & $\begin{array}{l}\mathbf{0 . 0 7 5 7} \\
0.1311\end{array}$ & & $\begin{array}{l}\mathbf{0 . 1 6 8 2} \\
0.1156\end{array}$ & & $\begin{array}{l}\mathbf{0 . 3 5 1 2} \\
0.0826\end{array}$ & $* * *$ & $\begin{array}{l}-- \\
--\end{array}$ & & $\begin{array}{l}\mathbf{0 . 3 1 1 1} \\
0.1227\end{array}$ & $* *$ \\
\hline$\alpha_{b}$ & $\begin{array}{l}\mathbf{0 . 1 6 3 6} \\
0.1084\end{array}$ & & $\begin{array}{r}0.2132 \\
--\end{array}$ & & $\begin{array}{l}\mathbf{0 . 0 8 7 7} \\
0.1252\end{array}$ & & $\begin{array}{l}\mathbf{0 . 4 9 4 6} \\
0.1085\end{array}$ & $* * *$ & $\begin{array}{r}0.4239 \\
--\end{array}$ & & $\begin{array}{l}\mathbf{0 . 2 9 5 9} \\
0.0839\end{array}$ & $* * *$ & $\begin{array}{l}\mathbf{0 . 1 3 8 9} \\
0.0663\end{array}$ & $* *$ & $\begin{array}{l}\mathbf{0 . 7 3 1 4} \\
0.0984\end{array}$ & $* * *$ & $\begin{array}{r}0.6488 \\
--\end{array}$ & & $\begin{array}{r}1.0000 \\
--\end{array}$ & & $\begin{array}{l}\mathbf{0 . 5 8 3 0} \\
0.0933\end{array}$ & $* * *$ \\
\hline$\alpha_{f}+\alpha_{b}-1$ & $\begin{array}{r}\mathbf{- 0 . 1 5 0 8} \\
0.2364\end{array}$ & & $\begin{array}{r}0.0000 \\
--\end{array}$ & & $\begin{array}{r}\mathbf{- 0 . 4 8 4 3} \\
0.3205\end{array}$ & & $\begin{array}{l}\mathbf{0 . 1 0 8 3} \\
0.1019\end{array}$ & & $\begin{array}{r}0.0000 \\
--\end{array}$ & & $\begin{array}{r}\mathbf{- 0 . 2 5 0 2} \\
0.0709\end{array}$ & $* * *$ & $\begin{array}{r}-\mathbf{0 . 7 8 5 4} \\
0.1635\end{array}$ & $* * *$ & $\begin{array}{r}\mathbf{- 0 . 1 0 0 4} \\
0.0367\end{array}$ & $* *$ & $\begin{array}{r}0.0000 \\
--\end{array}$ & & $\begin{array}{r}0.0000 \\
--\end{array}$ & & $\begin{array}{r}\mathbf{- 0 . 1 0 5 9} \\
0.0515\end{array}$ & $*$ \\
\hline$\beta$ & $\begin{array}{r}\mathbf{- 0 . 0 0 6 3} \\
0.0122\end{array}$ & & $\begin{array}{r}\mathbf{- 0 . 0 0 1 3} \\
0.0095\end{array}$ & & $\begin{array}{r}\mathbf{- 0 . 0 0 7 7} \\
0.0082\end{array}$ & & $\begin{array}{l}\mathbf{0 . 0 1 4 1} \\
0.0077\end{array}$ & * & $\begin{array}{l}\mathbf{0 . 0 1 3 3} \\
0.0055\end{array}$ & $* *$ & $\begin{array}{l}\mathbf{0 . 0 2 0 6} \\
0.0047\end{array}$ & $* * *$ & $\begin{array}{l}\mathbf{0 . 0 2 1 6} \\
0.0089\end{array}$ & $* *$ & $\begin{array}{l}\mathbf{0 . 0 1 7 5} \\
0.0052\end{array}$ & $* * *$ & $\begin{array}{l}\mathbf{0 . 0 1 3 9} \\
0.0051\end{array}$ & $* * * *$ & $\begin{array}{l}\mathbf{0 . 0 2 5 1} \\
0.0055\end{array}$ & $* * * *$ & $\begin{array}{l}\mathbf{0 . 0 1 3 1} \\
0.0039\end{array}$ & $* * *$ \\
\hline$\gamma_{m}$ & $\begin{array}{l}\mathbf{0 . 3 0 6 5} \\
0.1249\end{array}$ & $* *$ & $\begin{array}{l}\mathbf{0 . 2 6 9 0} \\
0.1104\end{array}$ & $* *$ & $\begin{array}{l}\mathbf{0 . 0 9 9 3} \\
0.0500\end{array}$ & * & $\begin{array}{r}-\mathbf{0 . 0 1 6 6} \\
0.0563\end{array}$ & & $\begin{array}{l}\mathbf{0 . 0 2 6 6} \\
0.0208\end{array}$ & & $\begin{array}{l}\mathbf{0 . 0 6 0 6} \\
0.0303\end{array}$ & * & $\begin{array}{l}\mathbf{0 . 2 4 4 9} \\
0.0507\end{array}$ & $* * * *$ & $\begin{array}{l}\mathbf{0 . 0 5 0 7} \\
0.0211\end{array}$ & $* *$ & $\begin{array}{l}\mathbf{0 . 0 1 7 1} \\
0.0113\end{array}$ & & $\begin{array}{l}\mathbf{0 . 0 1 3 0} \\
0.0168\end{array}$ & & $\begin{array}{l}\mathbf{0 . 0 9 0 0} \\
0.0342\end{array}$ & $* *$ \\
\hline$\gamma_{\eta}$ & $\begin{array}{r}\mathbf{- 0 . 9 5 5 2} \\
0.3036\end{array}$ & $* * *$ & $\begin{array}{r}\mathbf{- 1 . 0 5 4 4} \\
0.2598\end{array}$ & $* * *$ & $\begin{array}{r}\mathbf{- 0 . 3 5 3 8} \\
0.1608\end{array}$ & $* *$ & $\begin{array}{r}\mathbf{- 0 . 4 7 0 6} \\
0.2540\end{array}$ & * & $\begin{array}{r}\mathbf{- 0 . 4 8 5 5} \\
0.2149\end{array}$ & $* *$ & $\begin{array}{r}\mathbf{- 0 . 3 3 7 0} \\
0.1290\end{array}$ & $* *$ & $\begin{array}{l}\mathbf{0 . 0 8 5 4} \\
0.2624\end{array}$ & & $\begin{array}{r}-\mathbf{0 . 0 8 6 0} \\
0.1073\end{array}$ & & $\begin{array}{r}-\mathbf{0 . 1 7 6 7} \\
0.1020\end{array}$ & * & $\begin{array}{r}\mathbf{- 0 . 0 7 7 7} \\
0.1390\end{array}$ & & $\begin{array}{r}\mathbf{- 0 . 1 8 4 1} \\
0.0892\end{array}$ & $* *$ \\
\hline$\gamma_{e}$ & & & & & & & & & & & $\begin{array}{l}\mathbf{0 . 3 3 3 3} \\
0.0369\end{array}$ & $* * *$ & $\begin{array}{l}\mathbf{0 . 3 5 3 6} \\
0.0467\end{array}$ & $* * *$ & & & & & & & & \\
\hline $\begin{array}{l}\hat{\sigma}{ }^{b} \\
J \text {-test }\end{array}$ & $\begin{array}{l}0.0459 \\
0.8166\end{array}$ & & $\begin{array}{l}0.0476 \\
0.8463\end{array}$ & & $\begin{array}{l}0.0360 \\
0.8931\end{array}$ & & $\begin{array}{l}0.0857 \\
0.8193\end{array}$ & & $\begin{array}{l}0.0817 \\
0.8599\end{array}$ & & $\begin{array}{l}0.0543 \\
0.7466\end{array}$ & & $\begin{array}{l}0.0599 \\
0.6522\end{array}$ & & $\begin{array}{l}0.0153 \\
0.3266\end{array}$ & & $\begin{array}{l}0.0139 \\
0.3610\end{array}$ & & $\begin{array}{l}0.0182 \\
0.2799\end{array}$ & & $\begin{array}{l}0.0169 \\
0.4721\end{array}$ & \\
\hline
\end{tabular}

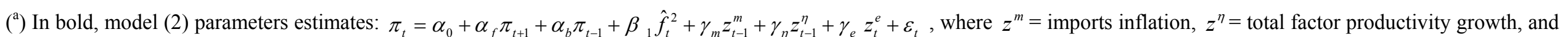

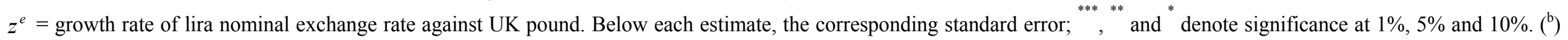
Standard error of the regression. $\left({ }^{c}\right)$ P-value of Hansen's (1982) over-identification restrictions test. 
Fig. 1 - Comparison of alternative output gap measures by sub-period $a$
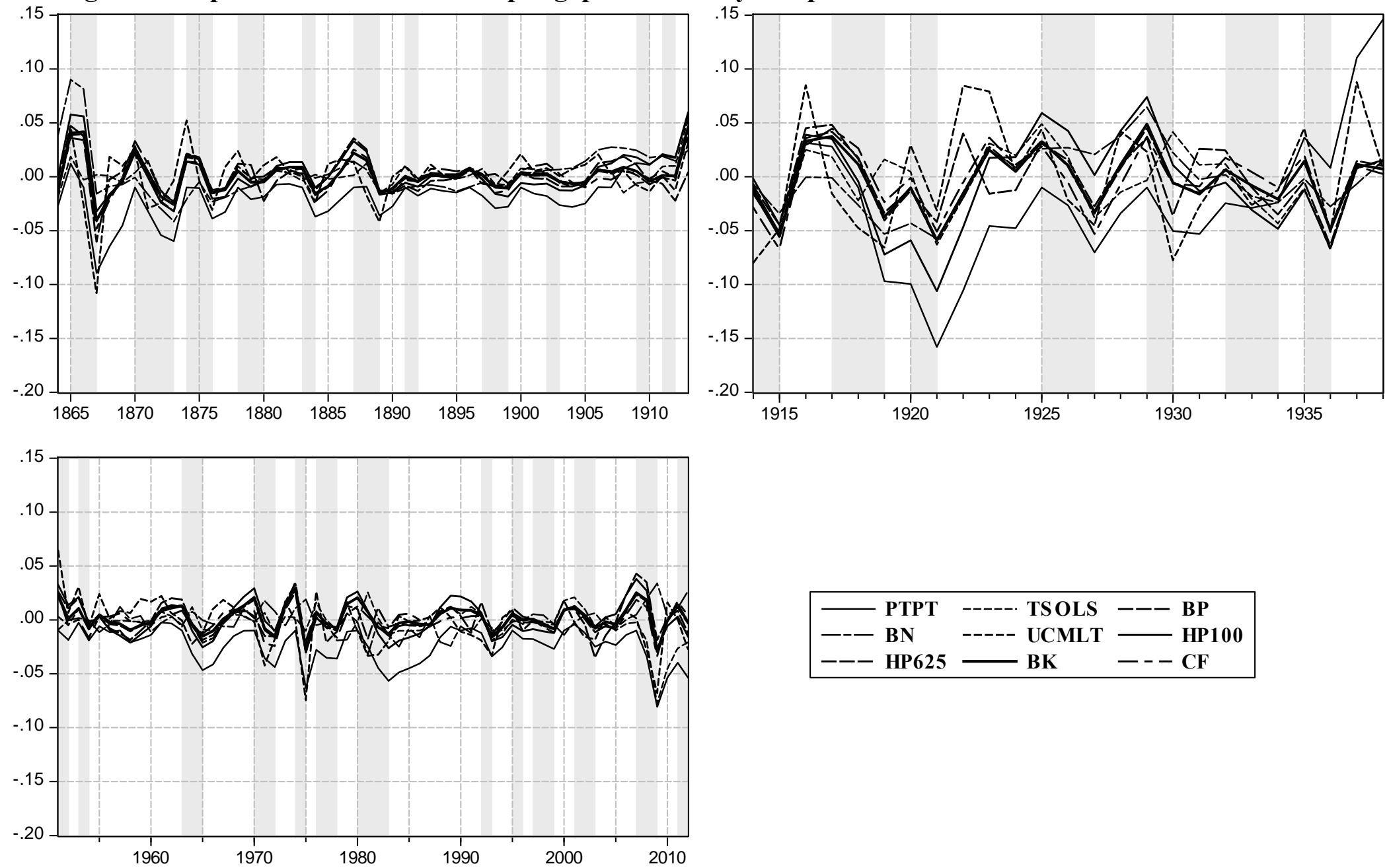

\begin{tabular}{|lll|}
\hline- PTPT & ---- TS OLS & --- BP \\
-- BN & ---- UCMLT & HP100 \\
--- HP625 & - BK & --- CF \\
\hline
\end{tabular}

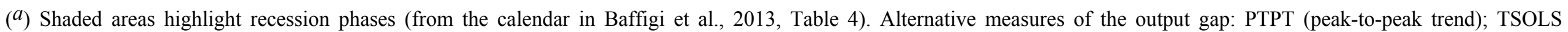

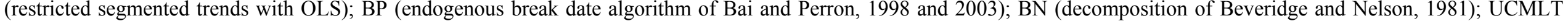

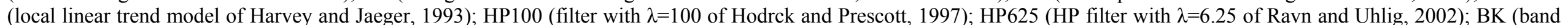
pass filter of Baxter and King, 1999); CF (band pass filter of Christiano and Fitzgerald, 2003); technical details are in Appendix A2. 
Fig. 2 - Time pattern of the first principal component of nine alternative output gaps $a$
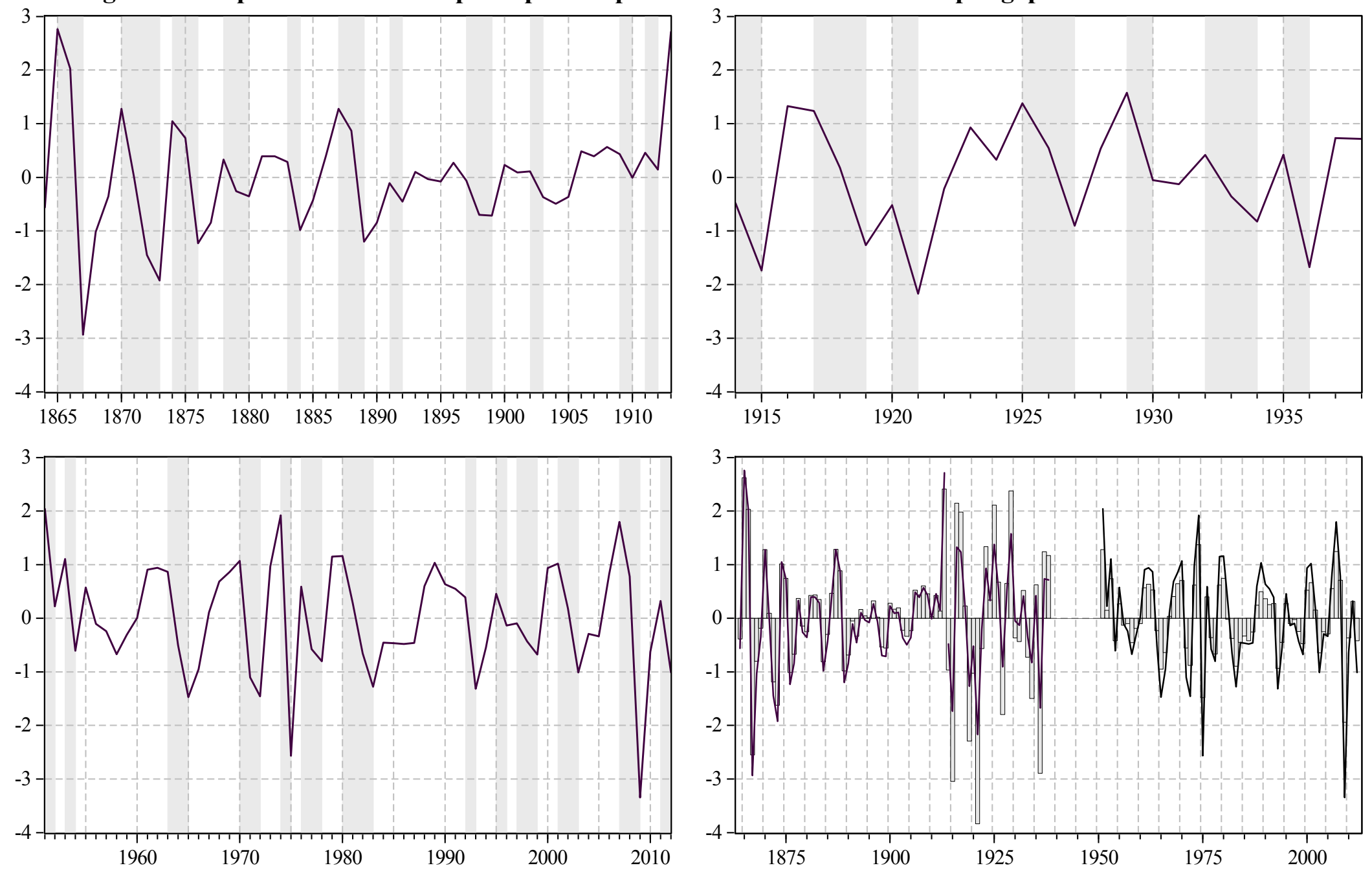

(a) Shaded areas highlight recession phases (from the calendar in Baffigi et al., 2013, Table 4). The first three quadrants report the time pattern of ${ }_{1} \hat{f}_{t}^{1}$ by sub-period; the last quadrant (bottom right) compares ${ }_{1} \hat{f}_{t}^{2}$ (bins) and ${ }_{1} \hat{f}_{t}^{1}$ (line); see Appendix A3. 